\title{
Manufacturing of Machine for Planting on Wide Ridges Without Tillage in Desert Soils
}

\author{
Adil Abd Elsamia Meselhy ${ }^{1, *}$, Mohamed Fathy Abou Youssef ${ }^{2}$, Ahmed El-Kot $^{1}$ \\ ${ }^{1}$ Agricultural Mechanization, Soil and Water Conservation Department - Desert Research Center, Cairo, Egypt \\ ${ }^{2}$ Soil Conservation, Soil and Water Conservation Department - Desert Research Center, Cairo, Egypt
}

Email address:

adil_meselhy@yahoo.com (A. A. E. Meselhy)

${ }^{*}$ Corresponding author

\section{To cite this article:}

Adil Abd Elsamia Meselhy, Mohamed Fathy Abou Youssef, Ahmed El-Kot. Manufacturing of Machine for Planting on Wide Ridges Without Tillage in Desert Soils. International Journal of Applied Agricultural Sciences. Vol. 7, No. 1, 2021, pp. 16-37.

doi: $10.11648 /$ j.ijaas.20210701.12

Received: November 14, 2020; Accepted: January 5, 2021; Published: January 15, 2021

\begin{abstract}
This research was conducted during three winter seasons (2015-2016), (2016-2017) and (2017-2018) at Ras Sudr Research Station, South of Sinai Governorate, this region suffers from the problems of increasing salinity in soil and irrigation water, in addition to the high level of ground water. Therefore, the cultivation on wide ridges (raised-bed soil) was used for good soil leaching by storing large quantities of irrigation water in these wide ridges and easy drainage it from both sides of the ridges to the adjacent furrows. The wide ridges are considered one of the methods of remedy the rise in ground water level by raising the agricultural soil to a higher level, which helps to move the roots of plants away from the ground water level and to drain the irrigation water through the ridges sides to the adjacent furrows, which does not cause an increase in the ground water level. Also, conservation tillage (no-tillage) reducing the effect of salinity. So that a prototype of combined machine was manufactured which consisted of two units, the first unit to build ridges with the possibility to change the both of width and height of ridges. The second unit to sow wheat seeds on the ridges. The research treatments consisted of two tillage systems (traditional tillage system (TT) and conservation tillage system (CT) i.e., no-tillage), three ridge widths $(50 \mathrm{~cm}, 70 \mathrm{~cm}$ and $90 \mathrm{~cm})$ and four ridge heights $(0 \mathrm{~cm}, 20 \mathrm{~cm}, 35 \mathrm{~cm}$ and $50 \mathrm{~cm})$ where, the treatment of $(0 \mathrm{~cm})$ was indicated to control treatment (flat soil). Also, the effect of three agriculture seasons was studied. Some parameters were measured or estimated as the following; actual field capacity (AFC), field efficiency (FE)), energy requirements (ER), pulling force (PF), fuel consumption rate (FCR), bulk density (BD), average infiltration rate (AIR), soil salinity (SS), water stored in the effective root zone (WS), water consumptive use in root zone (WC), water application efficiency (WA), wheat grain yield (WGY), water productivity (WP) and specific cost of production (SC). When using $(\mathrm{CT})$ system and the largest cross section area of the ridges $(90 \mathrm{~cm}$ width $\mathrm{x} 50 \mathrm{~cm}$ height) with continued application of this system for three consecutive seasons achieved the highest values of: $(\mathrm{AFC}=0.39 \mathrm{ha} / \mathrm{h}),(\mathrm{FE}=93 \%),\left(\mathrm{WS}=5773 \mathrm{~m}^{3} / \mathrm{ha}\right)$, $\left(\mathrm{WC}=4834 \mathrm{~m}^{3} / \mathrm{ha}\right),(\mathrm{WA}=89 \%),(\mathrm{WGY}=8.7 \mathrm{Mg} / \mathrm{ha})$ and $\left(\mathrm{WP}=1.8 \mathrm{Mg} / \mathrm{m}^{3}\right)$, in addition this treatment achieved the lowest values for both $(\mathrm{SS}=6.17 \mathrm{ds} / \mathrm{m})$ and $(\mathrm{SC}=216 \mathrm{~L} . \mathrm{E} / \mathrm{Mg})$ compared to the other treatments.
\end{abstract}

Keywords: Conservation Tillage, Irrigation Water Consumption, Raised-bed Soil, Wheat Crop, Wide Ridges

\section{Introduction}

Raised-bed (wide ridge) defines by is a soil raised above the surrounding ground level (approximately $15-50 \mathrm{~cm}$ height) in which the soil is formed in $(70-120 \mathrm{~cm}$ wide) beds, which can be of any length or shape. The desired outcomes from this management are to: drain, aerate, prevent water logging, increase root growth, thereby reinforce the loose structure, increase soil organic matter, increase plant water use, reduce deep drainage and increase production [1]. Advantages of raised bed planting for wheat crop. The raised bed planting in wheat crop saved $(50 \%$ seed and 30-40\% water), increased yield, reduced lodging, facilitated mechanical weeding, offered opportunity for a last irrigation at grain filling stage of wheat, avoided temporary water logging problem and reduced $\mathrm{N}$ loses [2].

The benefit of raised bed planting system with furrow irrigation compared with conventional flat planting and found that the raised bed minimizes water requirements (water saving about 30\%) and provide better drainage 
conditions. Raised bed planting system also provides opportunities for the precise application of fertilizers and hence minimized environmental hazards. The present economic recession has seriously threatened the farmer globally by raising inputs prices like hybrid seed, fertilizers, weedicides, pesticides and diesel for machinery. In these perspectives, the raised bed planting technique is gaining momentum for saving inputs and economic cost for wheat cultivation. It also eliminated the formation of crust on soil surface [3]. Raised bed planting system promotes crop intensification and diversification besides saving irrigation water. In raised bed system, saves $30-40 \%$ water as compared to conventional flood irrigation practice. Benefits of raised bed system also include (i) fewer weeds, (ii) facilitates seeding into relatively dry soils (iii) vigorous and better crop stands, (iv) savings of costly seed (v) reduced crop-lodging, seed and fertilizer contact (vi) better drainage, improved rainwater conservation and crop productivity and (vii) minimizes wilt infestation in crops like pigeon pea and avoids temporary water logging problems [4].

Bread wheat is the most widely grown and consumed food crop and is the staple food for $35 \%$ of the world population. Wheat is considered one of the most important and strategically crops in Egypt, but its area produced only about $30 \%$ of the domestic needs [5]. Yield has been increased up to $8 \%$ because plant receives more sunlight and energy on raised beds [6]. Raised bed system increasing crop yield because imparting higher nitrogen use efficiency and reducing lodging over condensational tillage sowing system [7]. The vegetables planting on the raised beds in the ridge furrow system achieves better growth conditions as, it realizes low levels of ground water and height infiltration. The optimum dimensions of bed profile width that achieve the maximum productivity [8]. The farmers get various products from wheat crop such as wheat straw which makes hay for animals, but wheat grain yield is the ultimate goal of the farmers, therefore, in many breeding and agronomic research programs the researchers mainly focused on achieving high wheat yield using various technologies including effects of different sowing methods [9]. Wheat planted on raised beds and furrow irrigation showed higher yield and water use efficiency than flat-planted wheat [10]. Ortega et al. Growing of crops on raised bed compared to a flat bed or conventional method could be stand and increased crop productivity [11]. The average root length, root spread and root weight of wheat plant extracted from the soil were higher in raised bed sowing as compared to conventional method [12]. The average grain yield of wheat increased by $5.5 \%$ in raised bed planting technique compared to conventional sowing [13]. Raised bed enhances fertilizer use efficiency due to efficient root system. This technique is not affordable by many smallholder farmers due to economic constraints as it involves the use of expensive heavy machinery [14]. Planting wheat on raised bed improved and efficient management of irrigation water; improved fertilizer use efficiency; better weed management; lower seed rate and better plant stands; better drainage and less lodging of wheat [15]. Weed infestation was reducing if wheat is planting on raised beds and improves soil fertility and structure, reduces soil erosion, water requirement and cons port several crops in complex relays or intercropping and rotation [16]. Wheat flat planting with flood irrigation leads to inferior water use efficiency and lower crop yield. This practice also results in greater crop lodging and enhanced frequency of crop diseases [17]. Raised bed planting systems, wheat crop sowed on the raised beds in ridge-furrow system. This system often considered more appropriate for growing high value crops that are more sensitive to temporary water logging stress. Moreover, that system of raised bed planting of crops may be particularly advantageous in areas where groundwater levels are falling and herbicide-resistant weeds are becoming a problem. Wheat yields improved by $10 \%$ with the proper variety, production costs can fall by 20 to $30 \%$, and irrigation water requirements can be reduced up to $35 \%$ compared to conventional planting on the flat soil [18].

The lodging problem is less on raised bed [19]. When wheat is grown on flat field, flood irrigation creates a wet condition around roots that reduces the binding of soil to support the plant. However, use of raised bed technology not only saves irrigation water, but also prevents the wet soil surface around the roots to avoid lodging especially under windy conditions [20]. Wheat planting technique on raised bed improved mechanical weed control, water and fertilizer use efficiencies and proved as most economical. Also, water saving and easy drainage of excess water after irrigation [21]. The soil on the surface of the raised bed is drier, which is not favorable for weed growth [22]. Raised bed technology showed less lodging as compared to flat sowing as well as $11.2 \%$ increase in grain yield along with $40-50 \%$ saving in irrigation water. The experiment also revealed that the raised bed planting method may be less susceptible to adversities of climate change because it portrays better ability to plant roots anchorage on beds and ability to withstand water stress [23]. Raised beds are reportedly saving $25-30 \%$ irrigation water and increasing water use efficiency [24]. Raised-bed providing better opportunities to leach salts from the furrows. However, under saline conditions [25].

Conservation tillage defines as any tillage and planting system that leaves at least 30 percent of the soil surface covered by residue after planting Conservation tillage increased soil moisture and water use efficiency of winter wheat [27]. The application of conservation tillage shown to reduce production costs and increase farm income [28]. Conservation tillage generally improvements soil moisture, water use efficiency, crop yield and economic [29]. Raised bed with conservation tillage facility more optimum planting time by providing timelier field access because of better drainage, addition once the bed established that are new opportunities to reduce crop turnaround time by re-using the same field without tillage [30]. Crop residues with no-tillage are important natural resource in the stability of agricultural ecosystems. About $25 \%$ of $\mathrm{N}$ and $\mathrm{P}$, $50 \%$ of $\mathrm{S}$ and $75 \%$ of $\mathrm{K}$ uptake by cereal crops can be retained in crop residues, making them valuable nutrient sources [31]. Crop residues with no-tillage has been 
identified as a promising management option to combat soil salinity, as it can decrease soil water evaporation, increase infiltration and regulate soil water and salt movement [32]. Raised-bed and conservation tillage help to reduce soil compaction by confining traffic to the furrows and to improve soil organic matter and physical characteristics owing to surface retention of residues [33]. There are several reports of saving irrigation water about (18\% to $50 \%$.) with similar or higher yields, for vegetable crops on raised beds with conservation tillage compared with conventional tillage crops [34]. The conservation tillage with raised bed planting system increased the wheat yield by $60 \%$ in long time with reduction in the cultivation cost by $24 \%$ compared with conventional system. Conservation-raised bed system improved water and fertilizer use efficiency by $20-25 \%$ and reduced the total production costs by nearly $30 \%$ [35].

Locally manufactured raised-bed machine developed for small-scale farms to improve water productivity in the Nile Delta of Egypt. He indicated that the developed machine has enabled the farmers to achieve remarkable results that include around $25 \%$ saving in applied water, around 50\% reduction in seed rate, around $25 \%$ decrease in farming cost, around $30 \%$ increase in fertilizer use efficiency, and around 15-25\% increase in crops yields [36].

Therefore, the objective of this study was to fabricate a prototype of machine for installing wide ridges (raised-bed soil) with different dimensions of cross sections area (width $\mathrm{x}$ height) and sowing wheat crop on its surface. In addition, evaluate of machine performance in terms of power requirements and operating costs. Moreover, evaluate the wheat crop sowing with raised-bed system compared to traditional system (flat soil) in terms of soil ability to retain moisture, improvement the water productivity, soil salinity and wheat crop productivity under two tillage systems (traditional and conservation)

\section{Materials and Methods}

This study was carried out at Ras-Sudr Research Station, South Sinai Governorate (latitude: $29^{\circ} 37^{\prime} 26^{\prime \prime} \mathrm{N}$, longitude: $32^{\circ} 42^{\prime} 43^{\prime \prime} \mathrm{E}$ and the elevation from sea surface $=36.2 \mathrm{~m}$ ), on calcareous sandy loam soil, which suffers from the problem of soil, and irrigation water salinity where, Salts in the soil-water solution decrease the amount of water available for plant uptake. Maintaining a higher soil-water content with more frequent irrigations relieves the effect of salt on plant moisture stress. A sandy loam is soil containing a high percentage of sand (Coarse sand $12.3 \%$ - Fine sand $58.7 \%$ ), but having enough silt (19.7\%) and clay $(9.3 \%)$ to make it somewhat coherent. The field experiment was carried out in the winter season 2015 and continuance to winter season 2017 (three winter seasons) with an experimental area of about $2.5 \mathrm{fed}$. which irrigated by drip irrigation system. Before the soil preparation directly, the average moisture content of soil surface layer $(0-30 \mathrm{~cm})$ was determined and found to be $18 \%$ (d.b.). Some chemical properties of the soil and well irrigation water were measured where, $\left(\mathrm{CaCO}_{3} 46.1 \%\right)$, (O.M 0.43\%), (pH 7.76 for soil and 7.89 for Irrigation water) and (E.C $10.5 \mathrm{ds} / \mathrm{m}$ for soil and $4.8 \mathrm{ds} / \mathrm{m}$ for Irrigation water).

\subsection{The Specifications of Fabricated Machine}

The prototype of fabricated machine which was used in this study to build the ridges (raised-bed soil) and sowing the wheat seeds is shown in Figures 1, 2 and 3. It is a mounted machine hitched on the tractor using the three points hitching system. The machine components were manufactured locally at the workshop in Quesna city, Menufiya Governorate. The total weight, length, width and height of machine were about of $320 \mathrm{Kg}, 1600 \mathrm{~mm}, 1450 \mathrm{~mm}$ and $1350 \mathrm{~mm}$ respectively. The machine consisted of the main following parts:

\subsubsection{Frame}

The frame of machine was manufactured from $10 \mathrm{~cm} \mathrm{~L}$ shapes iron, with a length of $1300 \mathrm{~mm}$, and width of $350 \mathrm{~mm}$. It was provided with some special bearing equipping each of hitching system, seeds hopper, establishing raised-bed unit, seed metering mechanism, and transmission system.

\subsubsection{Hitching System}

A three points hitching system manufactured locally from $20 \mathrm{~mm}$ thickness iron. The dimensions of that system are hitch pin diameter of $25 \mathrm{~mm}$, height of $600 \mathrm{~mm}$ and lower hitch point spread of $650 \mathrm{~mm}$.

\subsubsection{Seed Hopper}

An individual hopper has a prism configuration with trapezoid face shape. It was made from iron sheet with a thickness of $2 \mathrm{~mm}$. The maximum capacity of that hopper is about $60 \mathrm{Kg}$ of wheat seed. It also considered that the inclination angels of the hopper sides kept at 45 degrees, which is more than repose angels of wheat seeds (26 degrees -29 degrees) according to Satti et al (2012) [37].

\subsubsection{Unit of Establishing Ridges}

This unit used for establishing the ridges in the shape and dimensions of section area required (width $x$ height) in the study by heaping the soil which, previously plowed by traditional chisel plow 7 blades at two passes, $20 \mathrm{~cm}$ tillage depth and $4 \mathrm{~km} / \mathrm{h}$ forward speed then pressing the soil through the rear border box.

\subsubsection{THE seed Metering Mechanism}

The mechanism which picks up seeds from the seed box and delivers them into the seed tube is called seed metering mechanism. Seed metering mechanism in this seeder gear wheel types made of Teflon material. The feed wheel diameter of $(10 \mathrm{~cm})$, thickness of $(5 \mathrm{~cm})$. The seeder width consists of seven discs but in this study using four discs only to plant four rows on the raised bed of 90,70 and $50 \mathrm{~cm}$ with a space of 18 , 14 and $10 \mathrm{~cm}$ between rows respectively to ensure that the rate of sowing is equal. Each disc case has two holes the top is used as entry seed from the hopper to the disc cells, while the bottom hole is used as exit the seeds from the disc cells to the seeds planting tube and by consequently in the raised bed. The 
disc cells were equipped with the moving shaft in the iron case by means of a collecting unit.

\subsubsection{Transmission System}

It was designed to transmit the motion from the ground wheel (Dia. of $51.3 \mathrm{~cm}$ ) to the shaft of the feed disc through a sprocket gears to give equivalent rotation number related to the peripheral speed of the ground wheel.

\subsection{The Methods of Change Dimensions of Ridge Cross Section Area (Height $x$ Width) and Height of Soil Opener in Fabricated Machine}

The methods of change cross section area of ridges and height of soil opener are shown in Figures 4 and 5.

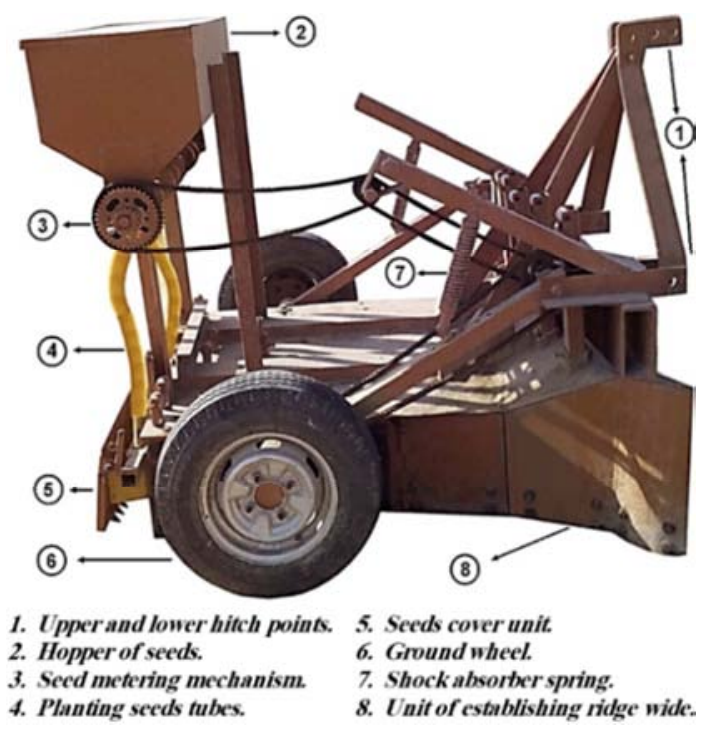

Figure 1. Side and front views of the prototype of fabricated machine.
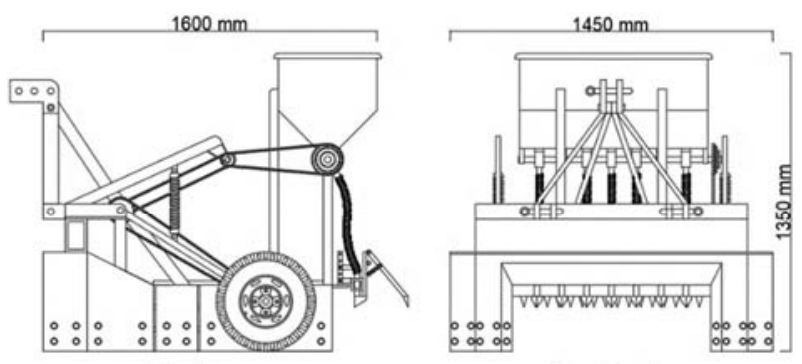

Side view

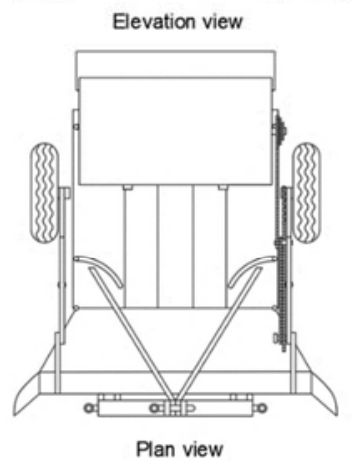

Figure 2. The sketched elevation, side and plan views of the manufactured prototype.
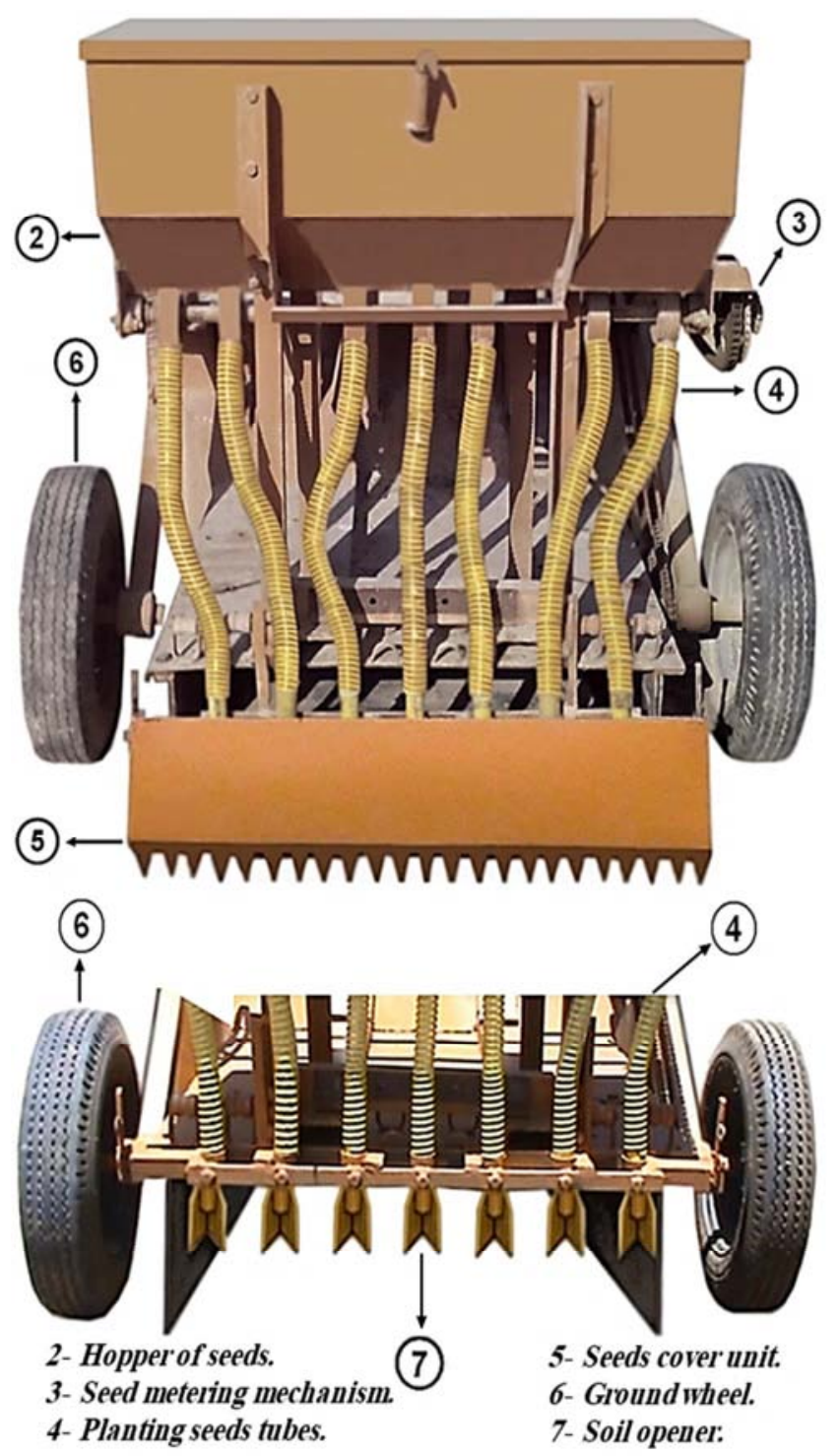

Figure 3. Back view of the prototype of fabricated machine.

\subsection{Specifications of Tractor}

Specifications of tractor were illustrated in Table 1:

Table 1. Specifications of tractor.

\begin{tabular}{ll}
\hline Tractor BELARUS Diesel engine - Model & D-243.1 \\
Net rated power & $90 \mathrm{hp}(66 \mathrm{~kW})$ at 2200 r.p.m \\
Number of cylinders & 4 cylinders \\
Weight, kg & 3460 \\
Max. trailing, kg & 8000 \\
Power take-off shaft & $540-1000 \mathrm{rpm}$ \\
Tires & \\
Front & $9.5-20$ \\
Rear & $15.5-38$ \\
Distance between wheels & \\
Front, mm & -1850 \\
Rear, mm & -2200 \\
\hline
\end{tabular}



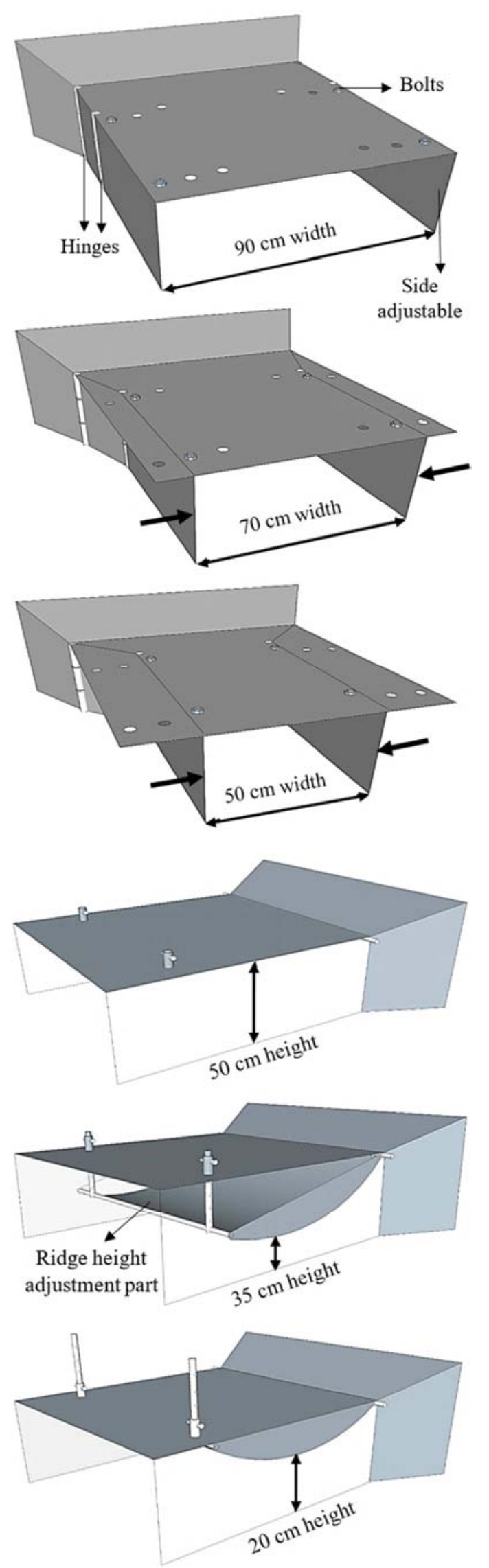

Figure 4. The method of change ridge dimensions (height and width).
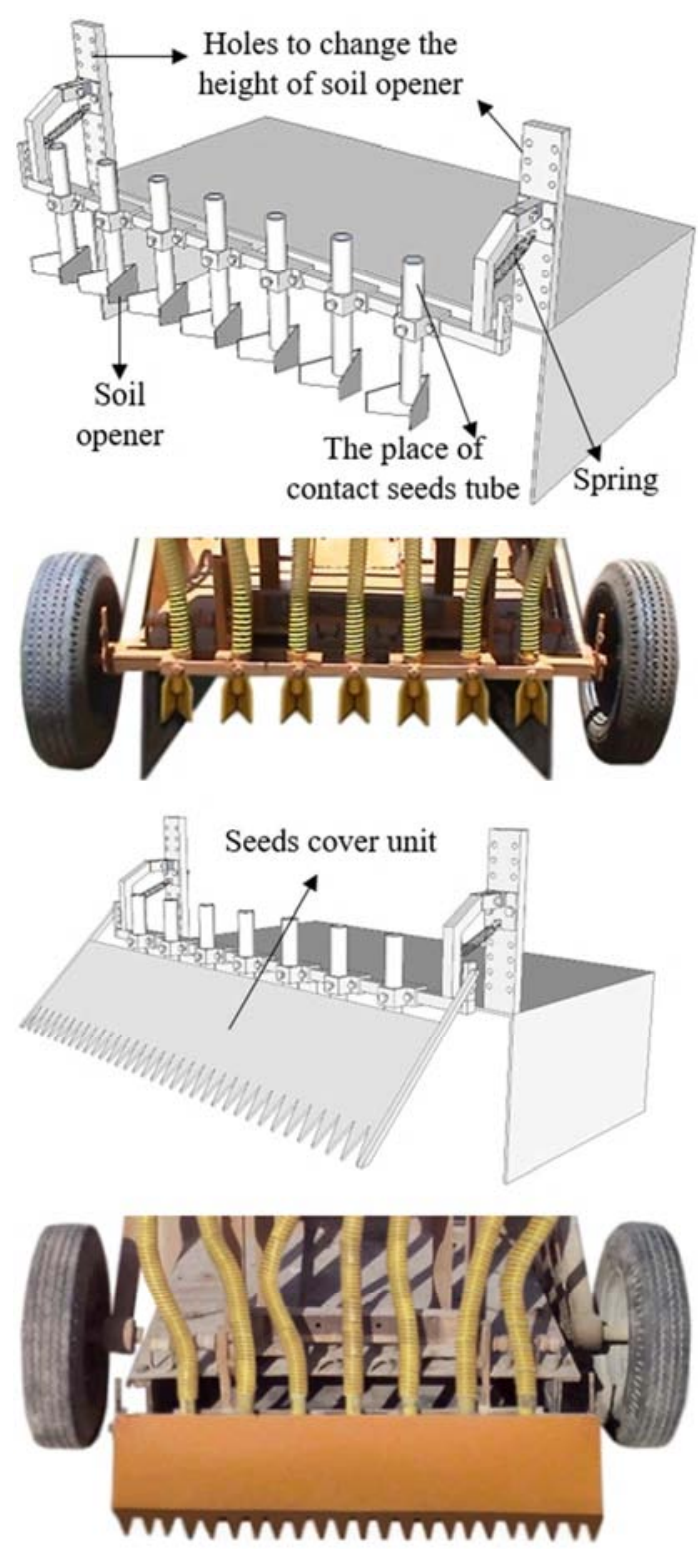

Figure 5. The method of change height of soil opener with seeds cover unit.

\subsection{Experimental Design}

The experimental area was about of one hectare. This experiment was established as split-split plots in three replicates, divided into main plot involved two levels of tillage system (traditional and conservation). Each main plot includes sub-plots, which involved three level of ridge width $(50,70$ and $90 \mathrm{~cm})$. Each sub-plot includes sub-sub plots, which involved four levels of the ridge height $(20,35$ and $50 \mathrm{~cm}$, raised-bed) in addition zero height to represent control plot or flat soil, resulted in a total of 72 plots, each of $150 \mathrm{~m}^{2}$. The previous experiment was carried out during three winter seasons where the wheat crop was planted. The first winter season began in 2015 with plowing the whole experiment by chisel plow 7blades (two passes at $20 \mathrm{~cm}$ tillage depth) after that construction the wide ridges under different treatments of study and sowing four rows of wheat seeds on the top of each ridge by fabricated machine and laying three drip irrigation 
tubes on each ridge. The second winter season 2016 the experiment was divided into two pieces. The first piece was planted by four rows of wheat seeds on the surface of ridge directly without tillage. The second piece was plowed using the chisel plow 7 blades (two passes at $20 \mathrm{~cm}$ tillage depth), and reconstructed the wide ridges under different treatments of study and sowing four rows of wheat seeds on the top of each ridge by fabricated machine. The third winter season 2017 was carried out the same way as the previous second season.

Note that, the summer season was planted by sorghum crop and forward speed of tractor was $4 \mathrm{~km} / \mathrm{h}$ for all treatments.

\subsection{Irrigation System}

Irrigation system in this study was drip irrigation. Three drip irrigation tubes were laying on each furrow as shown in Figures 6 and 7 which irrigates four rows of wheat crop.

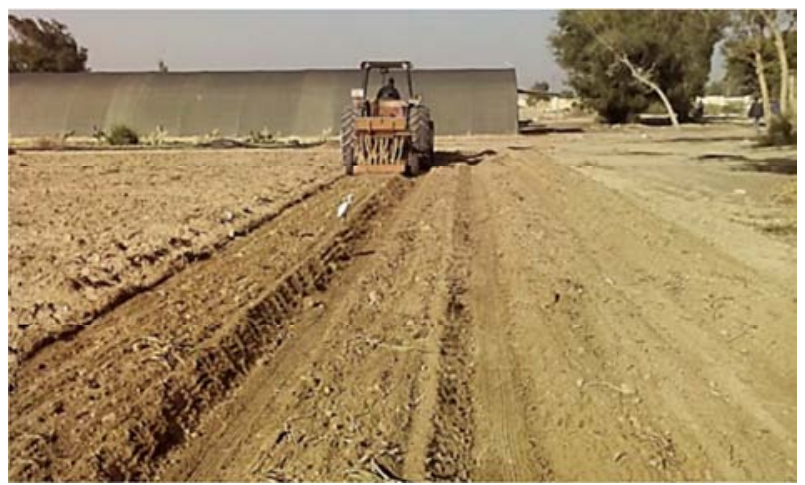

Figure 6. Establishing the ridges by machine in the field.

\subsection{Wheat Seeds and Planting Method}

The wheat crop (Sakha 93) was planted in mid-November in three consecutive winter seasons, with a rate of $140 \mathrm{~kg} / \mathrm{ha}$ by seeder unit in fabricated machine which consisted of seven rows for sowing crop seeds but in this study using four rows only to sow wheat seeds on the top of each ridge as shown in Figure 8 to sow the wheat seeds at the same rate for each ridge width $(50,70$ and $90 \mathrm{~cm})$. The Figures 9 and 10 were showed the wheat crop in germination stage and late stage respectively.

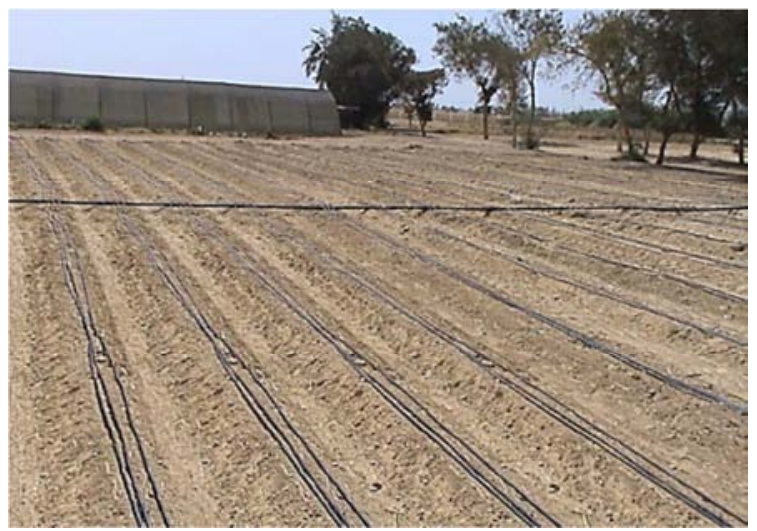

Figure 7. Drip irrigation net on the ridges.
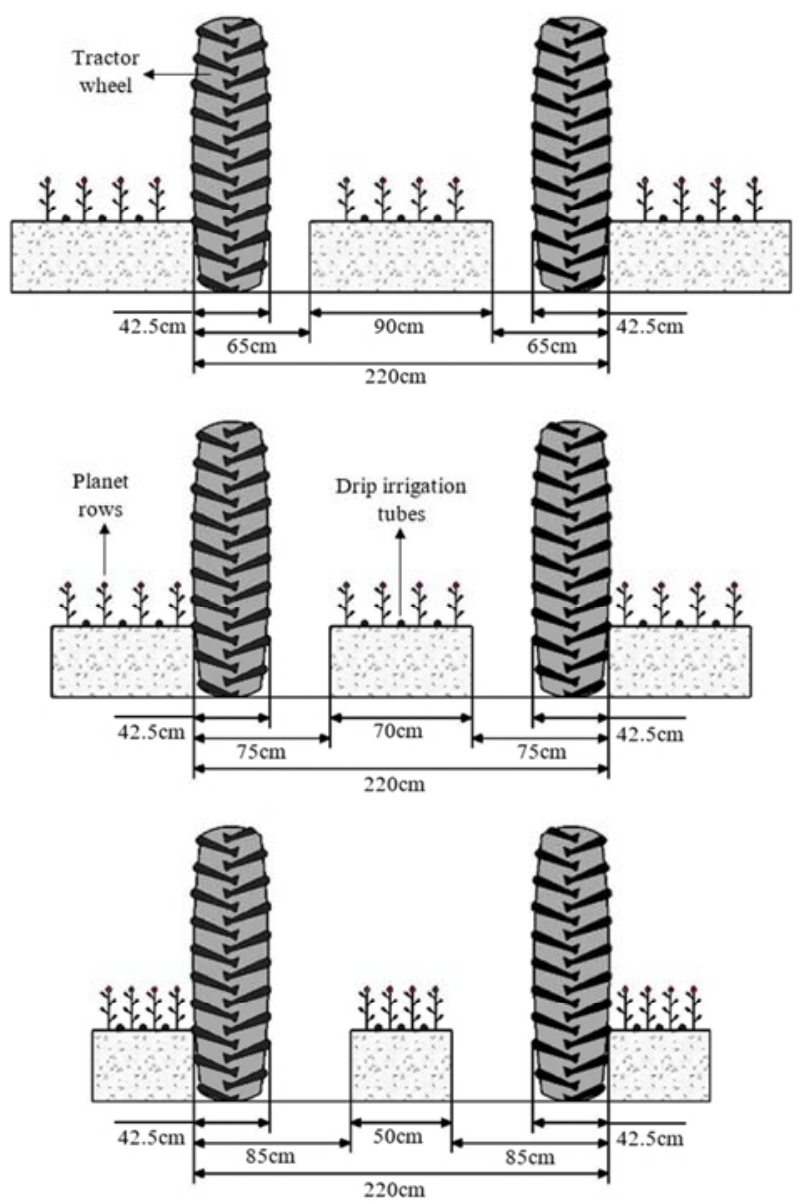

Figure 8. Sketch of spacing between ridges.

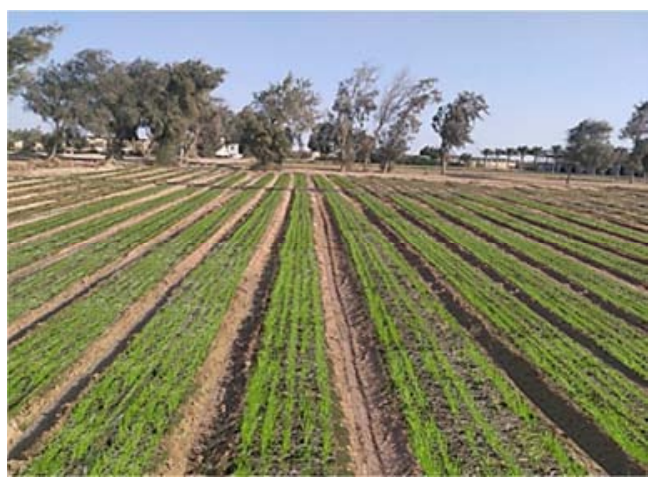

Figure 9. Wheat plants in germination stage.

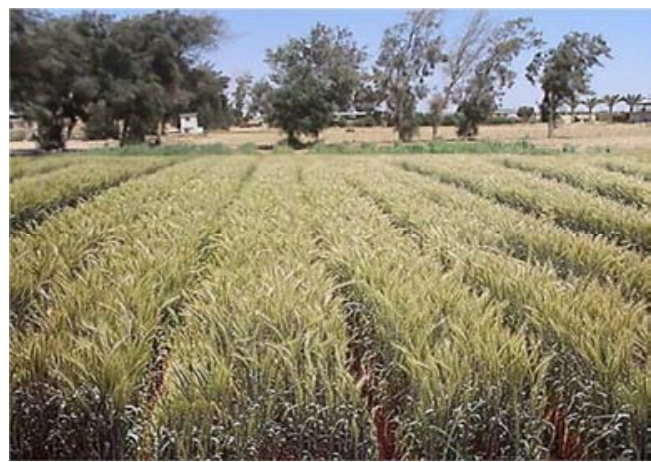

Figure 10. Wheat crop in late stage. 


\subsection{Measurements}

\subsubsection{Machine Performance Rate (Theoretical and Actual} Field Capacity and Field Efficiency)

Theoretical and actual field capacity and field efficiency were calculated by using equations mentioned by kepner et al. (1978) [38].

\subsubsection{Energy Requirements of Machine}

\section{(i). Pulling Force}

Pulling force was measured by hydraulic dynamometer, which was, coupled between the two tractors with the attaching machine to estimate its draught force. A considerable number of readings taken at a time interval 10 seconds to obtain an accurate average of draught force.

\section{(ii). Fuel Consumption Rate}

Fuel consumption per unit time was determined by measuring the volume of fuel consumed during operation time. It was measured using the fuel meter equipment as shown in Figure 11 the length of line which marked by the marker tool on the paper sheet represents the fuel consumption. The fuel meter was calibrated prior and the volume of fuel was determined accurately.

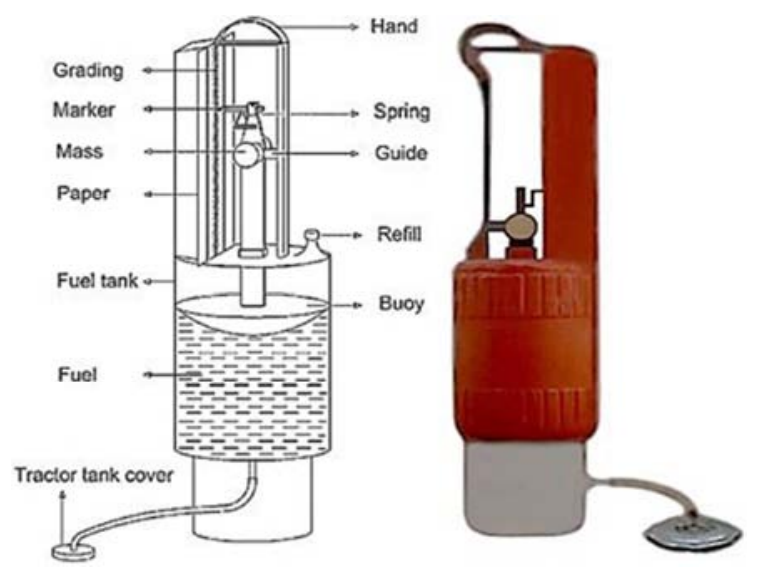

Figure 11. Fuel meter for measuring fuel consumption.

\subsubsection{Some Soil Physical Properties}

\section{(i). Soil Bulk Density}

Soil bulk density was measured using a core methods as described by Black (1986) [39].

\section{(ii). Average Infiltration Rate}

Infiltration characteristics of the studied soil was determined in the field by using a local made double ring (cylinder infiltrometer). The two cylinders were $30 \mathrm{~cm}$ deep and formed of steel sheet of $5 \mathrm{~mm}$ thickness which allow the cylinders to enter the soil with little disturbance. The inner cylinder, from which the infiltration measurements were taken, was $30 \mathrm{~cm}$ in diameter. The outer cylinder, which used to form the buffer pond was $60 \mathrm{~cm}$ in diameter. The double ring hammered into the soil to a depth of $15 \mathrm{~cm}$. Care was taken to keep the installation depth of the cylinder to be the same in all experiments. Average infiltration rates calculated by
Kostiakov equation (1932) [40]:

$$
\mathrm{I}=60 * \mathrm{c} * \mathrm{~T}^{\mathrm{m}-1}
$$

Where: $\mathrm{I}=$ Average infiltration rate, $(\mathrm{cm} / \mathrm{h}), \mathrm{c}, \mathrm{m}=$ Constants depend on soil properties and initial condition, and $\mathrm{T}=\mathrm{The}$ time after infiltration started (min).

\section{(iii). Soil Moisture Content and Soil Salinity}

Moisture measurement (TDR 300 soil moisture meter) Soil salinity (Direct soil EC probe).

\subsubsection{Crop Water Requirement}

Water requirement calculated using the Reference Evapotranspiration $\left(\mathrm{ET}_{\mathrm{o}}\right)$ and the Crop coefficients $\left(\mathrm{K}_{\mathrm{C}}\right)$ by the following equation:

$$
\mathrm{ETc}=\mathrm{ET}_{\mathrm{o}} * \mathrm{~K}_{\mathrm{C}}
$$

Where: $\quad$ Etc $=$ Crop Evapotranspiration (mm/day), $\mathrm{ETo}=$ Reference Evapotranspiration $(\mathrm{mm} /$ day $)$ and $\mathrm{Kc}=\mathrm{Crop}$ coefficients.

Table 2. Growth stages, Reference evapotranspiration, crop coefficient and Crop Evapotranspiration of wheat crop.

\begin{tabular}{lllll}
\hline Stage & $\begin{array}{l}\text { Duration } \\
\text { day }\end{array}$ & $\begin{array}{l}\text { ETo } \\
\mathbf{m m} / \mathbf{d a y}\end{array}$ & $\mathbf{K c}$ & $\begin{array}{l}\text { ETc } \\
\mathbf{m m} / \mathbf{d a y}\end{array}$ \\
\hline Initial & 20 & 2.1 & 0.5 & 1.05 \\
Development & 57 & 2.4 & 0.92 & 2.2 \\
Mid-season & 58 & 3.9 & 1.4 & 5.5 \\
Late & 25 & 4.2 & 0.89 & 3.69 \\
Total & 160 & 12.6 & 3.1 & 10.38 \\
\hline
\end{tabular}

Net irrigation requirement $\left(\mathrm{IR}_{\mathrm{n}}\right)$ is derived from the field balance equation:

$$
\mathrm{IR}_{\mathrm{n}}=\mathrm{ET}_{\mathrm{c}}-\mathrm{P}_{\mathrm{eff}}+\mathrm{LR}
$$

Where: $\quad \mathrm{IR}_{\mathrm{n}}=\mathrm{Net}$ irrigation requirement ( $\mathrm{mm} /$ day $)$, $\mathrm{ET}_{\mathrm{c}}=$ Crop evapotranspiration $(\mathrm{mm} /$ day $), \quad \mathrm{P}_{\text {eff }}=$ Effective dependable rainfall $(\mathrm{mm} /$ day) and $\mathrm{LR}=$ Leaching requirement (mm).

Gross irrigation requirements account for losses of water incurred during conveyance and application to the field.

$$
\mathrm{IR}_{\mathrm{g}}=\mathrm{IR}_{\mathrm{n}} / \mathrm{E}_{\mathrm{a}}
$$

Where: $\mathrm{IR}_{\mathrm{g}}=$ Gross irrigation requirements $(\mathrm{mm} /$ day), $\mathrm{IR}_{\mathrm{n}}=\mathrm{Net}$ irrigation requirement $\left(\mathrm{mm} /\right.$ day) and $\mathrm{E}_{\mathrm{a}}=$ Overall irrigation efficiency (\%). Therefore, the total water applied with leaching requirement (LR) for wheat crop under drip irrigation system $=6463 \mathrm{~m}^{3} / \mathrm{ha}$.

\subsubsection{Irrigation Water Measurements}

\section{(i). Water Stored in the Effective Root Zone}

Water stored in the root zone was determined according to James (1988) [41] as follows:

$$
\mathrm{WS}=\sum_{\mathrm{i}=1}^{\mathrm{i}=4}\left(\frac{\theta_{\mathrm{fc}}-\theta_{\mathrm{wp}}}{100}\right) \mathrm{D}_{\mathrm{r}} * \rho_{\mathrm{b}}
$$

Where: WS $=$ Water stored in the root zone, $(\mathrm{mm}), \Theta_{\mathrm{fc}}=$ Soil moisture content at field capacity, $(\%), \Theta_{\mathrm{wp}}=$ Soil moisture 
content at permanent wilting point, $(\%), \mathrm{D}_{\mathrm{r}}=$ Effective root depth, $(\mathrm{mm}), \rho_{\mathrm{b}}=$ Soil bulk density, $\left(\mathrm{g} / \mathrm{cm}^{3}\right)$ for depth and $\mathrm{I}=$ Number of soil layers (1-4).

\section{(ii). Water Consumptive Use in Effective Root Zone}

Water consumptive use by growing plants was calculated based on soil moisture depletion (SMD) according to Hansen et al. (1979) [42]

$$
\mathrm{Wcu}=\sum_{\mathrm{i}=1}^{\mathrm{i}=4}\left(\frac{\theta_{\mathrm{fc}}-\theta_{\mathrm{i}}}{100}\right) \mathrm{D}_{\mathrm{r}} * \rho_{\mathrm{b}}
$$

Where: $\mathrm{Wcu}=$ Water consumptive use in the effective root zone $(\mathrm{mm}), \Theta_{\mathrm{fc}}=$ Soil moisture content at field capacity, $(\%)$, $\Theta_{\mathrm{i}}=$ Soil moisture content before next irrigation, $(\%)$, $\mathrm{D}_{\mathrm{r}}=$ Effective root depth, $(\mathrm{mm}), \rho_{\mathrm{b}}=$ Soil bulk density, $\left(\mathrm{g} / \mathrm{cm}^{3}\right)$ for depth and $\mathrm{I}=$ Number of soil layers (1-4).

\section{(iii). Water Application Efficiency}

Water application efficiency (WAE) was calculated according to Israelsen and Hansen (1962) [43] as follows:

$$
\mathrm{WAE}=\left(\frac{\mathrm{WS}}{\mathrm{TWA}}\right) * 100
$$

Where: WAE=Water application efficiency $(\%), \mathrm{WS}=$ Water stored in the effective root zone $\left(\mathrm{m}^{3} / \mathrm{ha}\right)$ and TWA=Total water applied $\left(\mathrm{m}^{3} / \mathrm{ha}\right)$.

\section{(iv). Water Productivity}

Water productivity was determined according to Ali et al (2007) [44] as follows:

$$
\mathrm{WP}=\frac{\mathrm{Y}}{\mathrm{Wcu}}
$$

Where: $\mathrm{WP}=$ Water productivity $\left(\mathrm{kg} / \mathrm{m}^{3}\right), \quad \mathrm{Wcu}=$ Water consumptive used $\left(\mathrm{m}^{3} / \mathrm{ha}\right)$ and $\mathrm{Y}=$ Wheat grain yield $(\mathrm{kg} / \mathrm{ha})$.

\subsubsection{The Cost}

\section{(i). Total Cost of Performing a Tillage Operation}

Total hourly cost was determined according to EL-Awady (1978) [45] as follows:

$$
\begin{gathered}
\mathrm{C}=\left(\frac{\mathrm{p}}{\mathrm{h}}\right) *\left(\frac{1}{\mathrm{~L}}+\frac{\mathrm{i}}{2}+\mathrm{t}+\mathrm{r}\right)+(1.2 * \mathrm{RFC} * \mathrm{f})+\left(\frac{\mathrm{m}}{144}\right)+\left(\frac{\mathrm{P}_{1}}{\mathrm{~h}_{1}}\right) * \\
\left(\frac{1}{\mathrm{~L}_{1}}+\frac{\mathrm{i}}{2}+\mathrm{t}+\mathrm{r}_{1}\right)
\end{gathered}
$$

Where: $\mathrm{C}=$ Hourly cost, $(\mathrm{L} . \mathrm{E} . / \mathrm{h}), \mathrm{P}=$ Initial price of the tractor, (L.E), $\mathrm{h}=$ Yearly working hours of tractor. (h/year), $\mathrm{L}=$ Life expectancy of the tractor, (year), $\mathrm{T}=$ Annual taxes and overhead ratio, (\%), $\mathrm{f}=$ Fuel price, (L.E./L), $\mathrm{m}=$ The monthly average wage,(L.E./month), 1.2=Factor accounting for lubrications, $\mathrm{RFC}=$ Actual rate of fuel consumption, $(\mathrm{L} / \mathrm{h}), \mathrm{I}=$ Annual interest rate, $(\%), r=$ Annual repairs and maintenance ratio for tractor, $(\%), \mathrm{P}_{1}=$ Initial price of machine, (L.E), $\mathrm{h}_{1}=$ Yearly working hours of machine, ( $\mathrm{h} /$ year), $\mathrm{r}_{1}=$ Annual repairs and maintenance ratio for machine, $(\%), 144=$ Operator monthly average working hours, (h) and $\mathrm{L}_{1}$ : Life expectancy of machine.

\section{(ii). Total Cost per Unit Area}

Total cost per unit area was determined as follows:

$$
\mathrm{TCA}=\frac{\mathrm{C}}{\mathrm{AFC}}
$$

Where: $\mathrm{TCA}=$ Total cost per unit area, (L.E./ha), $\mathrm{AFC}=$ Actual field capacity, $(\mathrm{ha} / \mathrm{h})$ and $\mathrm{C}=$ Hourly cost, (L.E./h).

\section{(iii). Specific Cost of Production}

Specific cost of production was determined as follows:

$$
\mathrm{SCP}=\frac{\mathrm{TCA}}{\mathrm{Y}}
$$

Where: $\mathrm{SEC}=$ Specific cost of production, (L.E/Mg), $\mathrm{TCA}=$ Total cost per unit area, (L.E/ha) and $\mathrm{Y}=$ grain yield, ( $\mathrm{Mg} / \mathrm{ha})$.

\section{Results and Discussion}

The results in all study measurements showed that no significant effect of the tillage treatments in the first season, this is due to the use of the same traditional plowing method in the first season even before the implementation of the conservative tillage method to build the wide ridges, after that the results showed a significant effect of the tillage treatments in the following two seasons (second and third).

\subsection{Actual Field Capacity and Field Efficiency}

Tables 3, 4 and Figures 12, 13 showed that increasing in performance of fabricated machine when using conservation tillage system (no-tillage, no-rebuilding ridges and directly sowing) compared to traditional tillage system (tillage two passes at $20 \mathrm{~cm}$ depth, building ridges and sowing). The conservation tillage system achieved the average increasing percentage in actual field capacity and field efficiency, were about $49 \%$ and $10 \%$ respectively, compared to traditional tillage system. This result may be due to reduction in the number of machines using in conservation tillage system compared to traditional tillage system.

On other hand, the results showed that ridge width $90 \mathrm{~cm}$ achieved the average increasing percentage in actual field capacity and field efficiency, were about of $79 \%$ and $10 \%$ respectively, compared to ridge width $50 \mathrm{~cm}$. This result may be to when increasing operation width of machine, the actual field capacity and field efficiency increased. However, when decreasing ridges height from $50 \mathrm{~cm}$ to zero $\mathrm{cm}$ (flat soil) the actual field capacity and field efficiency increased by about $11 \%$ and $13 \%$ respectively. This can be explained by the fact that increasing the height of ridges, need more amount of soil to build it, which increases the working time.

The results indicated that, in general, increasing season's number increases the actual field capacity and field efficiency of the machine. So that the average increasing percentage in actual field capacity and field efficiency obtained with third season about $60 \%$ and $25 \%$ respectively, compared to the first season. Data showed that actual field capacity and field efficiency of machine increased about $6 \%$ and $8 \%$ respectively, when using flat soil system compared to wide ridge system (raised-bed soil). 
Table 3. Effect of study treatments on actual field capacity.

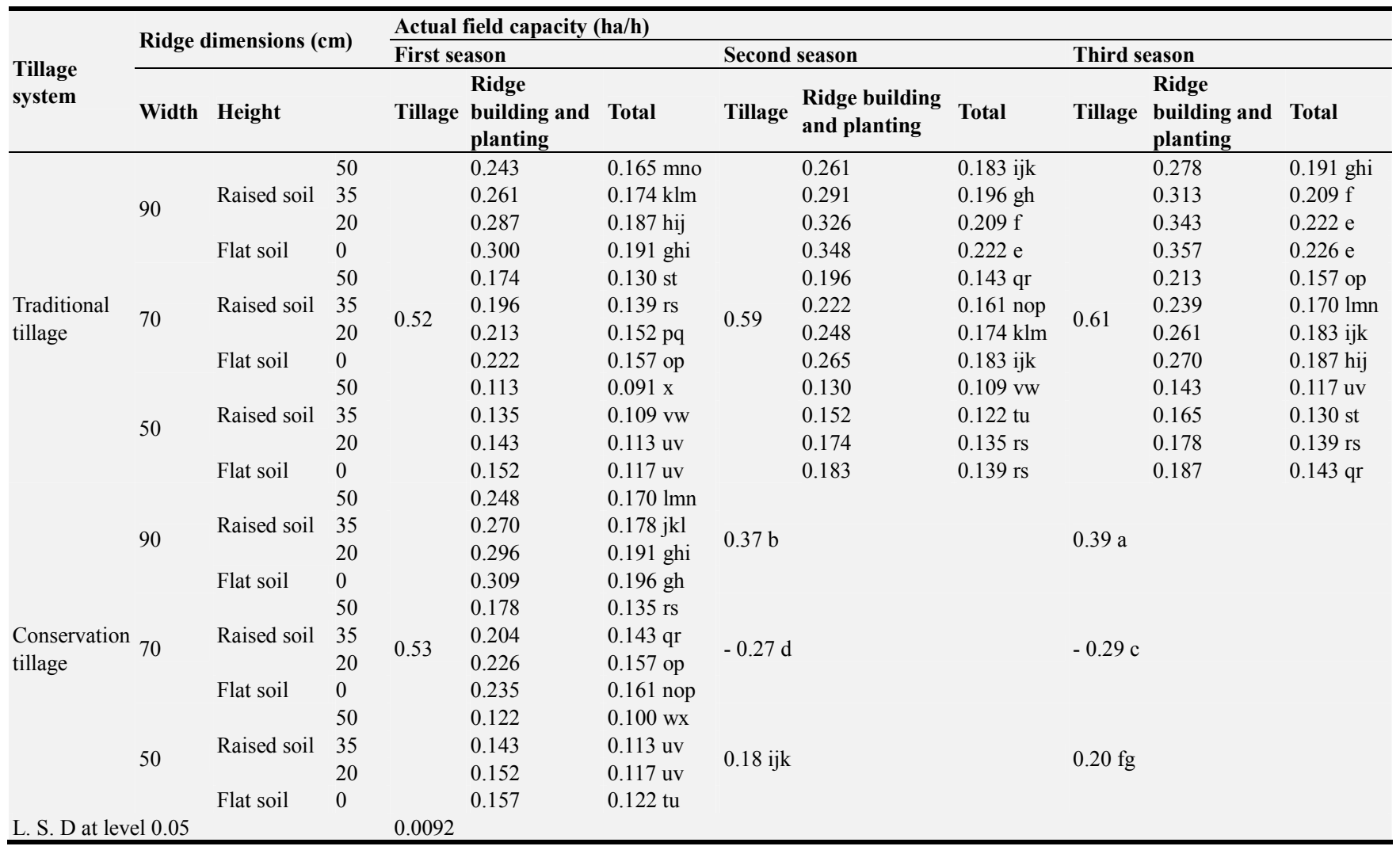

Values accompanied by the same letter in each row are not significantly different $(\mathrm{P}>0.05)$ using Duncan's multiple range test.

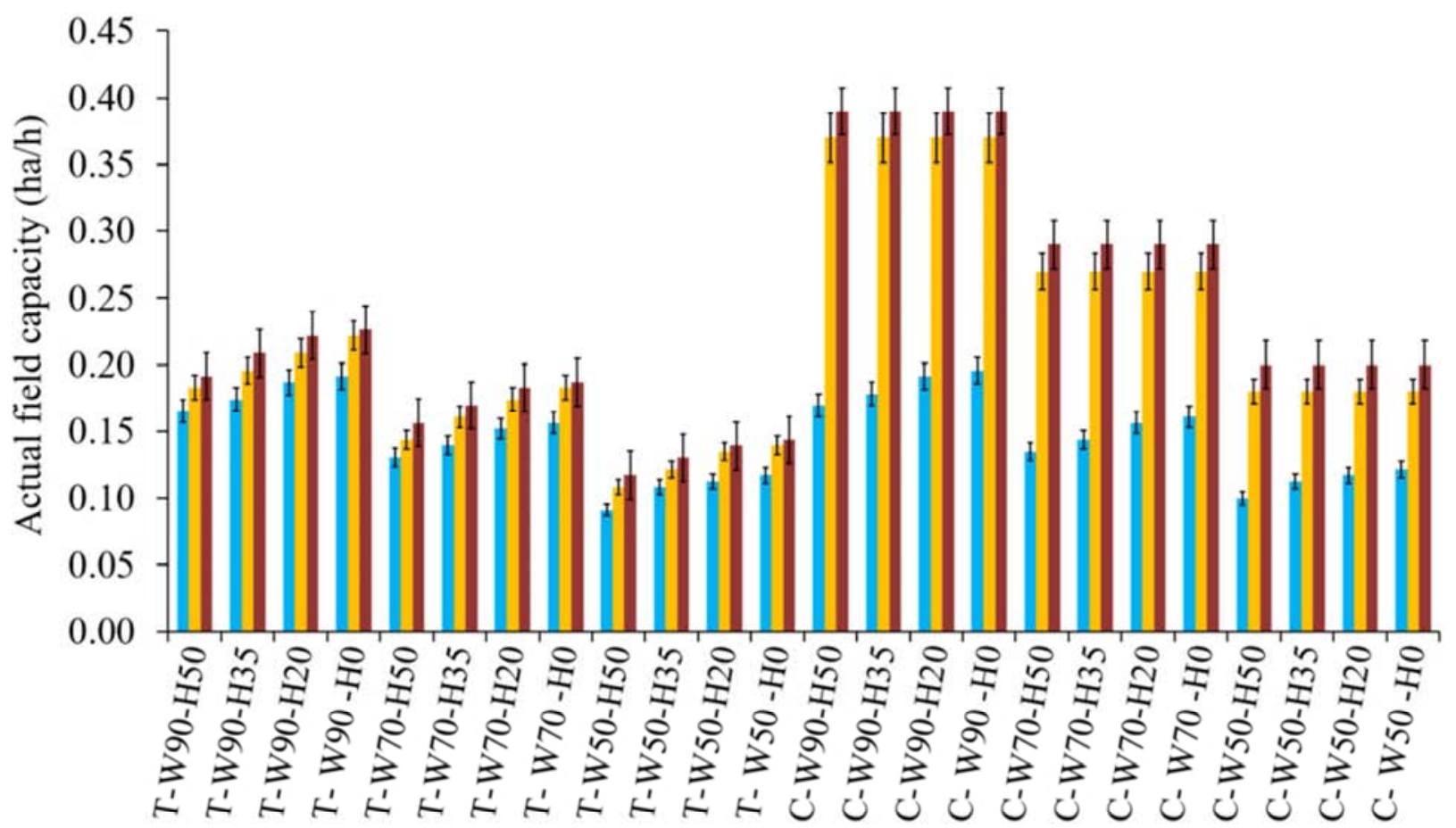

- First season $=$ Second season $\mathbf{m}$ Third season

The treatments

Figure 12. Effect of study treatments (T- traditional tillage, C-conservation tillage, $W$-ridge width at three levels $(90 \mathrm{~cm}, 70 \mathrm{~cm}$ and $50 \mathrm{~cm})$ and $H$-ridge height at three levels $(50 \mathrm{~cm}, 35 \mathrm{~cm}, 20 \mathrm{~cm}$ and $0 \mathrm{~cm}))$ on actual field capacity. Bars represent $S E s,(P>0.05)$. 
Table 4. Effect of study treatments on field efficiency.

\begin{tabular}{|c|c|c|c|c|c|c|c|c|c|c|c|c|}
\hline \multirow{3}{*}{$\begin{array}{l}\text { Tillage } \\
\text { system }\end{array}$} & \multirow{2}{*}{\multicolumn{3}{|c|}{ Ridge dimensions (cm) }} & \multicolumn{9}{|c|}{ Field efficiency (\%) } \\
\hline & & & & \multicolumn{3}{|c|}{ First season } & \multicolumn{3}{|c|}{ Second season } & \multicolumn{3}{|c|}{ Third season } \\
\hline & Width & Height & & Tillage & $\begin{array}{l}\text { Ridge } \\
\text { building and } \\
\text { planting }\end{array}$ & Total & Tillage & $\begin{array}{l}\text { Ridge } \\
\text { building and } \\
\text { planting }\end{array}$ & Total & Tillage & $\begin{array}{l}\text { Ridge } \\
\text { building and } \\
\text { planting }\end{array}$ & Total \\
\hline \multirow{10}{*}{$\begin{array}{l}\text { Traditional } \\
\text { tillage }\end{array}$} & \multirow{3}{*}{90} & \multirow{3}{*}{ Raised soil } & 50 & \multirow{10}{*}{75} & 58 & $63 \mathrm{qr}$ & \multirow{10}{*}{85} & 63 & $70 \mathrm{lmn}$ & \multirow{10}{*}{88} & 67 & $73 \mathrm{jk}$ \\
\hline & & & 35 & & 63 & 67 op & & 70 & $75 \mathrm{ij}$ & & 75 & $80 \mathrm{fg}$ \\
\hline & & & 20 & & 68 & $72 \mathrm{kl}$ & & 78 & $80 \mathrm{fg}$ & & 82 & $85 \mathrm{~cd}$ \\
\hline & \multirow{4}{*}{70} & Flat soil & 50 & & 53 & $59 \mathrm{st}$ & & 60 & $65 \mathrm{pq}$ & & 65 & $71 \mathrm{klm}$ \\
\hline & & \multirow[t]{2}{*}{ Raised soil } & 35 & & 60 & $63 \mathrm{qr}$ & & 68 & $73 \mathrm{jk}$ & & 73 & $76 \mathrm{hi}$ \\
\hline & & & 20 & & 65 & $69 \mathrm{mno}$ & & 76 & $78 \mathrm{gh}$ & & 80 & 82 ef \\
\hline & & \multirow[t]{2}{*}{ Flat soil } & 0 & & 68 & $71 \mathrm{klm}$ & & 81 & 82 ef & & 82 & $84 \mathrm{de}$ \\
\hline & \multirow{3}{*}{50} & & 50 & & 49 & $53 \mathrm{u}$ & & 57 & $63 \mathrm{qr}$ & & 62 & 68 no \\
\hline & & \multirow[t]{2}{*}{ Raised soil } & 35 & & 58 & $63 \mathrm{qr}$ & & 66 & $70 \mathrm{lmn}$ & & 71 & $75 \mathrm{ij}$ \\
\hline & & & 20 & & 62 & $65 \mathrm{pq}$ & & 75 & $78 \mathrm{gh}$ & & 77 & $80 \mathrm{fg}$ \\
\hline \multirow{12}{*}{$\begin{array}{l}\text { Conservation } \\
\text { tillage }\end{array}$} & \multirow{4}{*}{90} & Flat soil & 50 & & 59 & $65 \mathrm{pq}$ & \multirow{4}{*}{$89 \mathrm{~b}$} & 79 & $80 \mathrm{fg}$ & \multirow{4}{*}{$93 \mathrm{a}$} & & \\
\hline & & \multirow[t]{2}{*}{ Raised soil } & 35 & & 65 & 68 no & & & & & & \\
\hline & & & 20 & & 71 & 73 jk & & & & & & \\
\hline & & \multirow[t]{2}{*}{ Flat soil } & 0 & & 74 & $75 \mathrm{ij}$ & & & & & & \\
\hline & \multirow{4}{*}{70} & & 50 & & 55 & $61 \mathrm{rs}$ & & & & & & \\
\hline & & \multirow[t]{2}{*}{ Raised soil } & 35 & 76 & 63 & $65 \mathrm{pq}$ & $84 \mathrm{de}$ & & & $88 \mathrm{~h}$ & & \\
\hline & & & 20 & 10 & 69 & $71 \mathrm{klm}$ & $-84 \mathrm{de}$ & & & $-88 \mathrm{~b}$ & & \\
\hline & & Flat soil & 0 & & 72 & $73 \mathrm{jk}$ & & & & & & \\
\hline & & & 50 & & 52 & $58 \mathrm{t}$ & & & & & & \\
\hline & 50 & Raised soil & 35 & & 62 & $65 \mathrm{pq}$ & $79 \mathrm{~g}$ & & & $85 \mathrm{~cd}$ & & \\
\hline & 50 & & 20 & & 66 & 68 no & $19 \mathrm{~g}$ & & & $85 \mathrm{~cd}$ & & \\
\hline & & Flat soil & 0 & & 68 & $70 \mathrm{lmn}$ & & & & & & \\
\hline L. S. D at leve & 0.05 & & & 2.8466 & & & & & & & & \\
\hline
\end{tabular}

Values accompanied by the same letter in each row are not significantly different $(\mathrm{P}>0.05)$ using Duncan's multiple range test.

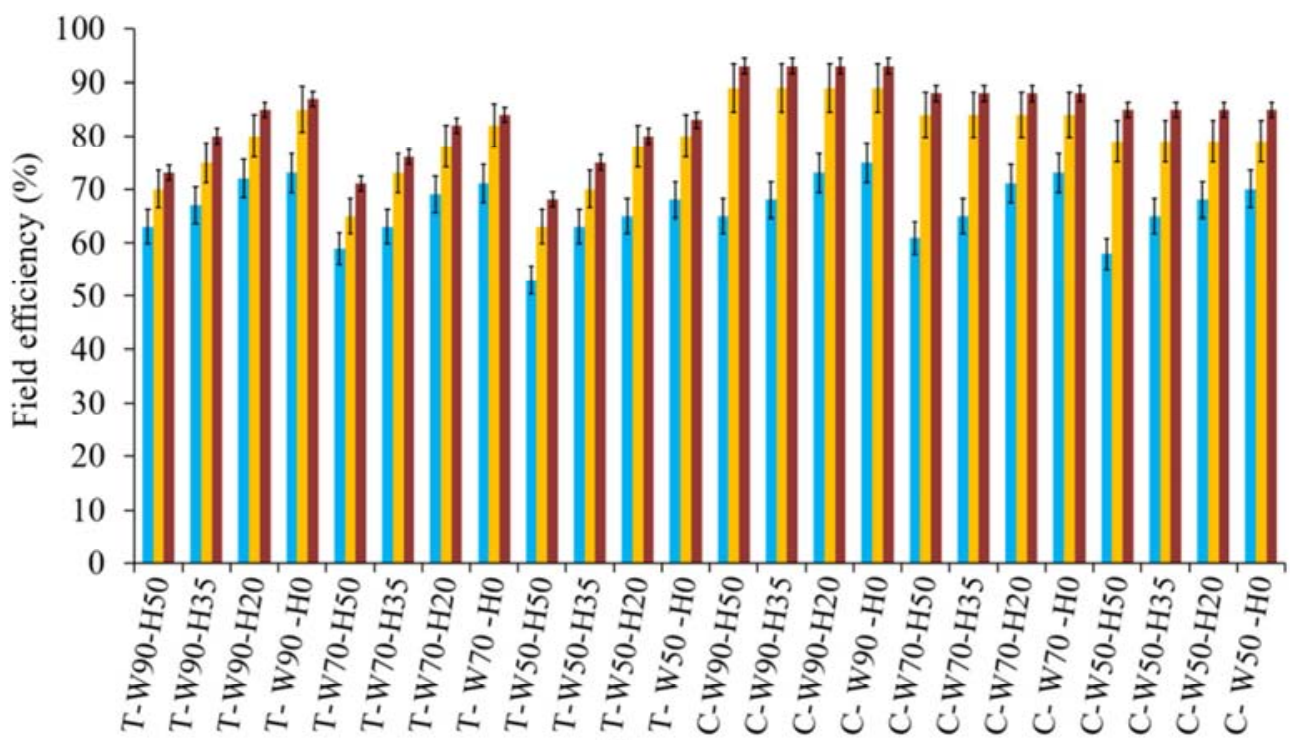

The treatments

m First season $=$ Second season $\mathbf{m}$ Third season

Figure 13. Effect of study treatments (T-traditional tillage, $C$-conservation tillage, $W$-ridge width at three levels (90cm, $70 \mathrm{~cm}$ and $50 \mathrm{~cm}$ ) and $H$-ridge height at three levels $(50 \mathrm{~cm}, 35 \mathrm{~cm}, 20 \mathrm{~cm}$ and $0 \mathrm{~cm}))$ on field efficiency. Bars represent $S E s,(P>0.05)$.

\subsection{Pulling Force and Fuel Consumption of Fabricated Machine}

Pulling force and fuel consumption of fabricated machine as affected by study treatments were presented in Tables 5, 6 and Figures 14, 15. Reducing pulling force and fuel consumption of the machine is the objective to be achieved. In the tillage system treatment, the average decreasing percentage in pulling force and fuel consumption were about $52 \%$ and $53 \%$, respectively, for conservation tillage compared to traditional tillage. The decreasing in pulling force and fuel consumption were obtained with conservation tillage may be 
attributed to that the operations of tillage and ridges construction in conservation tillage system were limited to the first season only. However, during the second and third seasons, sowing process on the ridges which, established previously was carried out only in the first season. So that in the first season two machines were used i.e. the chisel plow to tillage and fabricated machine to build ridges and sowing, but in the second and third seasons did not use the both of chisel plow and the unit of building ridges, but only the sowing unit in the fabricated machine was used.

Also, in the ridge width treatment, the average decreasing percentage in pulling force and fuel consumption were about $12 \%$ and $14 \%$, respectively, for ridge width $50 \mathrm{~cm}$ compared to ridge width $90 \mathrm{~cm}$. However, the treatment of ridge height zero $\mathrm{cm}$ (flat soil) achieved the highest decreasing percentage in pulling force and fuel consumption were about $40 \%$ and $37 \%$, respectively, compared to $50 \mathrm{~cm}$ ridge height. These results may be due to the fact that when increasing the ridges dimensions (width and height) this requires a large amount of soil to build it, which consumed more energy. The continuation of application wide ridges system during successive seasons led to decrease the machine energy consumption for two types of tillage systems. In the traditional tillage system, the average decreasing percentage of pulling force and fuel consumption in third season were about of $17 \%$ and $18 \%$, respectively, compared to the first season. This can be attributed to the fact that the ridges which built in first season were more friable so that plowed these ridges in the second season to rebuild new, need less energy compared to plow the flat soil before first season where the soil is more cohesive.

In conservation tillage system, the average decreasing percentage in pulling force and fuel consumption in the third season, about of $86 \%$ and $88 \%$, respectively, compared to the first season. This result may be attributed to that, in the conservation tillage system the flat soil was plowed in the first season only to build ridges then built ridges and sowing it but in the second and third seasons carried out one operation i.e. sowing on the previous ridges, which established in the first season (without tillage). So that in conservation tillage system, at the first season using chisel plow and both of two units of fabricated machine but at the second and third seasons using sowing unit only therefore, energy requirements in the third season lower than the first season in conservation tillage system.

Generally, in conservation tillage system, the reduction of energy consumption was higher than traditional tillage system, because conservation tillage system using sowing unit only of fabricated machine without tillage but in the traditional tillage system using chisel plow to tillage and both of two unit of fabricated machine to build ridges and sowing.

The results showed that pulling force and fuel consumption rate of machine decreased about $35 \%$ and $31 \%$ respectively, when using flat soil system compared to wide ridge system (raised-bed soil).

Table 5. Effect of study treatments on pulling force.

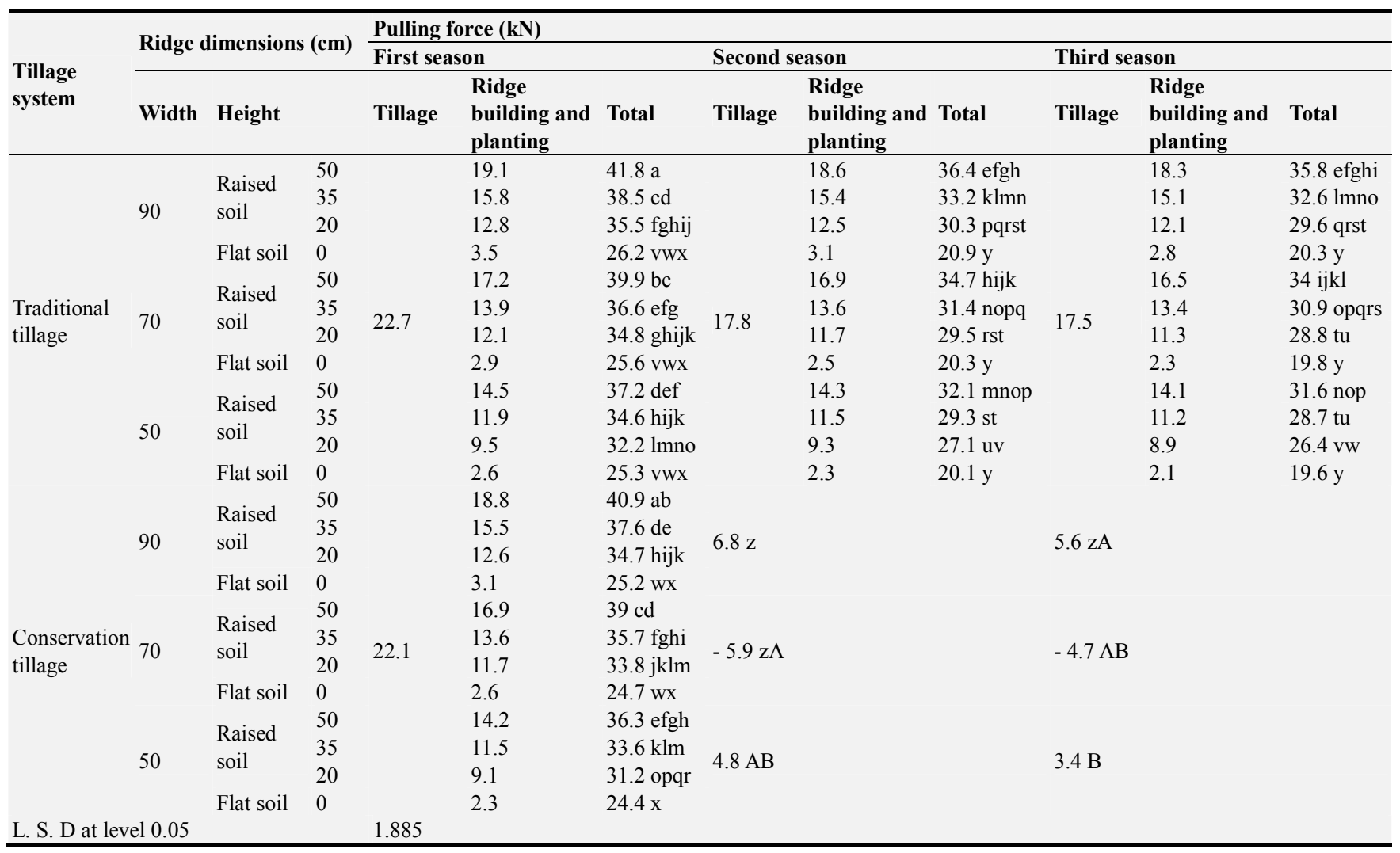

Values accompanied by the same letter in each row are not significantly different $(\mathrm{P}>0.05)$ using Duncan's multiple range test. 


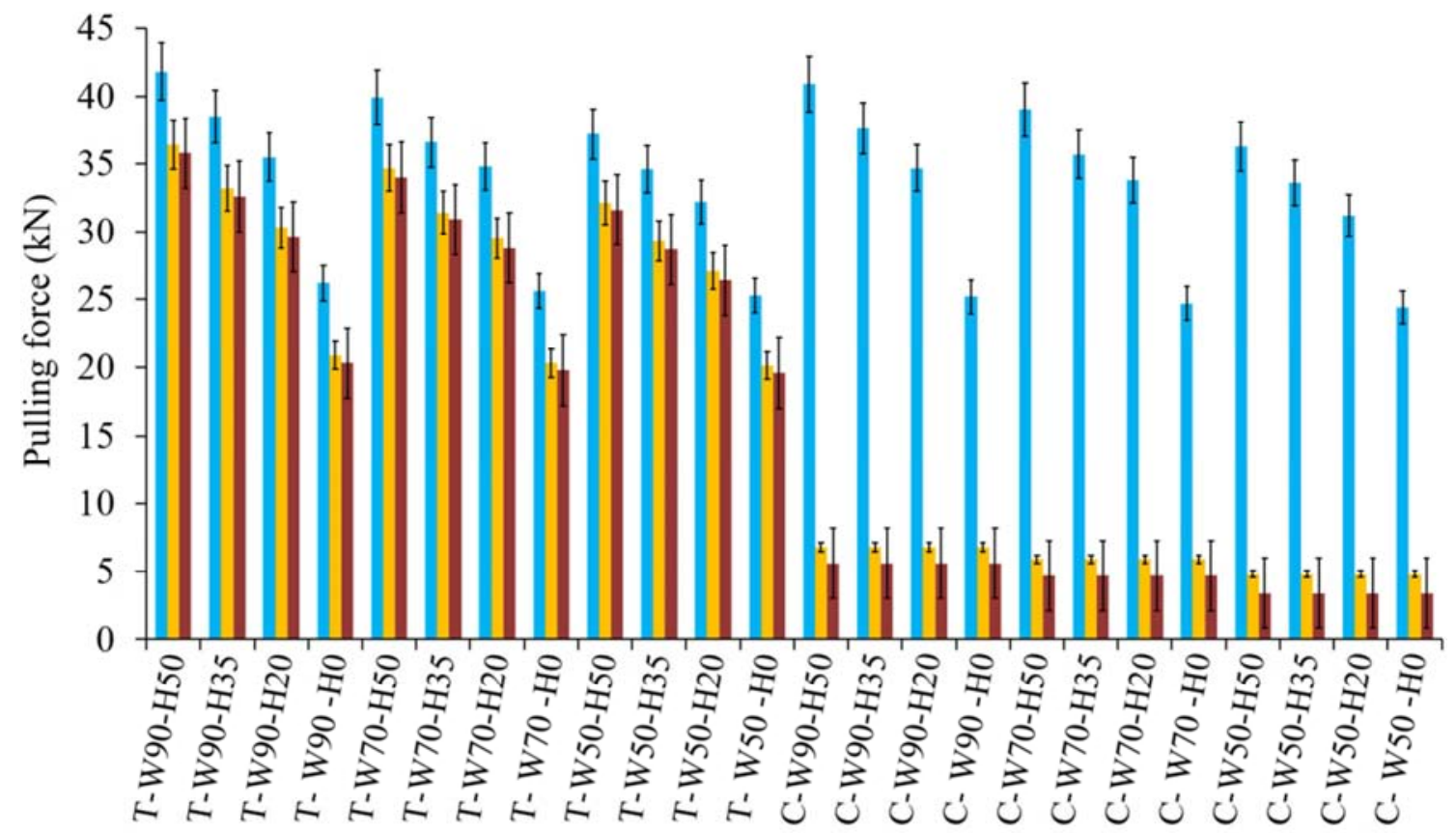

- First season $\|$ Second season $\square$ Third season

The treatments

Figure 14. Effect of study treatments (T-traditional tillage, C-conservation tillage, $W$-ridge width at three levels $(90 \mathrm{~cm}, 70 \mathrm{~cm}$ and $50 \mathrm{~cm})$ and $H$-ridge height at three levels $(50 \mathrm{~cm}, 35 \mathrm{~cm}, 20 \mathrm{~cm}$ and $(0 \mathrm{~cm}))$ on pulling force. Bars represent $S E s,(P>0.05)$.

Table 6. Effect of study treatments on fuel consumption.

\begin{tabular}{|c|c|c|c|c|c|c|c|c|c|c|c|c|}
\hline \multirow{3}{*}{$\begin{array}{l}\text { Tillage } \\
\text { system }\end{array}$} & \multirow{2}{*}{\multicolumn{3}{|c|}{ Ridge dimensions (cm) }} & \multicolumn{9}{|c|}{ Fuel consumption $(\mathrm{L} / \mathrm{h})$} \\
\hline & & & & \multicolumn{3}{|c|}{ First season } & \multicolumn{3}{|c|}{ Second season } & \multicolumn{3}{|c|}{ Third season } \\
\hline & Width & Height & & Tillage & $\begin{array}{l}\text { Ridge } \\
\text { building and } \\
\text { planting }\end{array}$ & Total & Tillage & $\begin{array}{l}\text { Ridge } \\
\text { building and } \\
\text { planting }\end{array}$ & Total & Tillage & $\begin{array}{l}\text { Ridge } \\
\text { building and } \\
\text { planting }\end{array}$ & Total \\
\hline \multirow{10}{*}{$\begin{array}{l}\text { Traditional } \\
\text { tillage }\end{array}$} & \multirow{3}{*}{90} & \multirow[b]{2}{*}{ Raised soil } & 50 & \multirow{10}{*}{20.2} & 17.4 & $37.6 \mathrm{a}$ & & 17.1 & $32.7 \mathrm{~cd}$ & & 16.9 & $32.1 \mathrm{de}$ \\
\hline & & & 35 & & 13.2 & $33.4 \mathrm{c}$ & & 13.1 & $28.7 \mathrm{jk}$ & & 12.8 & $28 \mathrm{kl}$ \\
\hline & & Flat soil & 0 & & 2.6 & $22.8 \mathrm{st}$ & & 2.5 & $18.1 \mathrm{x}$ & & 2.2 & 17.4 xy \\
\hline & \multirow{4}{*}{70} & & 50 & & 15.1 & $35.3 \mathrm{~b}$ & & 14.8 & $30.4 \mathrm{fg}$ & & 14.6 & $29.8 \mathrm{gh}$ \\
\hline & & Raised soil & 35 & & 12.6 & $32.8 \mathrm{~cd}$ & 156 & 12.3 & 27.91 & 150 & 12.1 & $27.3 \mathrm{lmn}$ \\
\hline & & & 20 & & 10.3 & $30.5 \mathrm{fg}$ & 15.0 & 10.1 & 25.7 op & 15.2 & 9.8 & $25 \mathrm{pqr}$ \\
\hline & & Flat soil & 0 & & 1.9 & 22.1 tuv & & 1.8 & $17.4 \mathrm{xy}$ & & 1.7 & $16.9 \mathrm{yz}$ \\
\hline & \multirow{3}{*}{50} & & 50 & & 12.1 & $32.3 \mathrm{de}$ & & 11.8 & $27.4 \mathrm{lmn}$ & & 11.7 & $26.9 \mathrm{n}$ \\
\hline & & Raised soil & 35 & & 9.4 & $29.6 \mathrm{hi}$ & & 9.2 & $24.8 \mathrm{qr}$ & & 9.1 & $24.3 \mathrm{r}$ \\
\hline & & Flat soil & 0 & & 1.5 & 21.7 uvw & & 1.4 & $17 \mathrm{yz}$ & & 1.3 & $16.5 \mathrm{z}$ \\
\hline \multirow{12}{*}{$\begin{array}{l}\text { Conservation } \\
\text { tillage }\end{array}$} & \multirow{4}{*}{90} & & 50 & & 17.1 & $36.9 \mathrm{a}$ & \multirow{4}{*}{$5.3 \mathrm{~A}$} & & & \multirow{4}{*}{$4.4 \mathrm{~B}$} & & \\
\hline & & Raised soil & 35 & & 12.9 & $32.7 \mathrm{~cd}$ & & & & & & \\
\hline & & & 20 & & 10.1 & $29.9 \mathrm{gh}$ & & & & & & \\
\hline & & Flat soil & 0 & & 2.4 & 22.2 stuv & & & & & & \\
\hline & \multirow{4}{*}{70} & & 50 & & 14.8 & $34.6 \mathrm{~b}$ & \multirow{4}{*}{$-4.5 \mathrm{~B}$} & & & \multirow{4}{*}{$-3.6 \mathrm{C}$} & & \\
\hline & & Raised soil & 35 & 198 & 12.3 & $32.1 \mathrm{de}$ & & & & & & \\
\hline & & & 20 & 19.0 & 10.1 & $29.9 \mathrm{gh}$ & & & & & & \\
\hline & & Flat soil & 0 & & 1.7 & $21.5 \mathrm{vw}$ & & & & & & \\
\hline & \multirow{4}{*}{50} & & 50 & & 11.8 & $31.6 \mathrm{e}$ & \multirow{4}{*}{$3.4 \mathrm{C}$} & & & \multirow{4}{*}{$2.5 \mathrm{D}$} & & \\
\hline & & Raised soil & 35 & & 9.2 & $29 \mathrm{ij}$ & & & & & & \\
\hline & & & 20 & & 7.3 & $27.1 \mathrm{mn}$ & & & & & & \\
\hline & & Flat soil & 0 & & 1.3 & $21.1 \mathrm{w}$ & & & & & & \\
\hline
\end{tabular}

Values accompanied by the same letter in each row are not significantly different $(\mathrm{P}>0.05)$ using Duncan's multiple range test. 


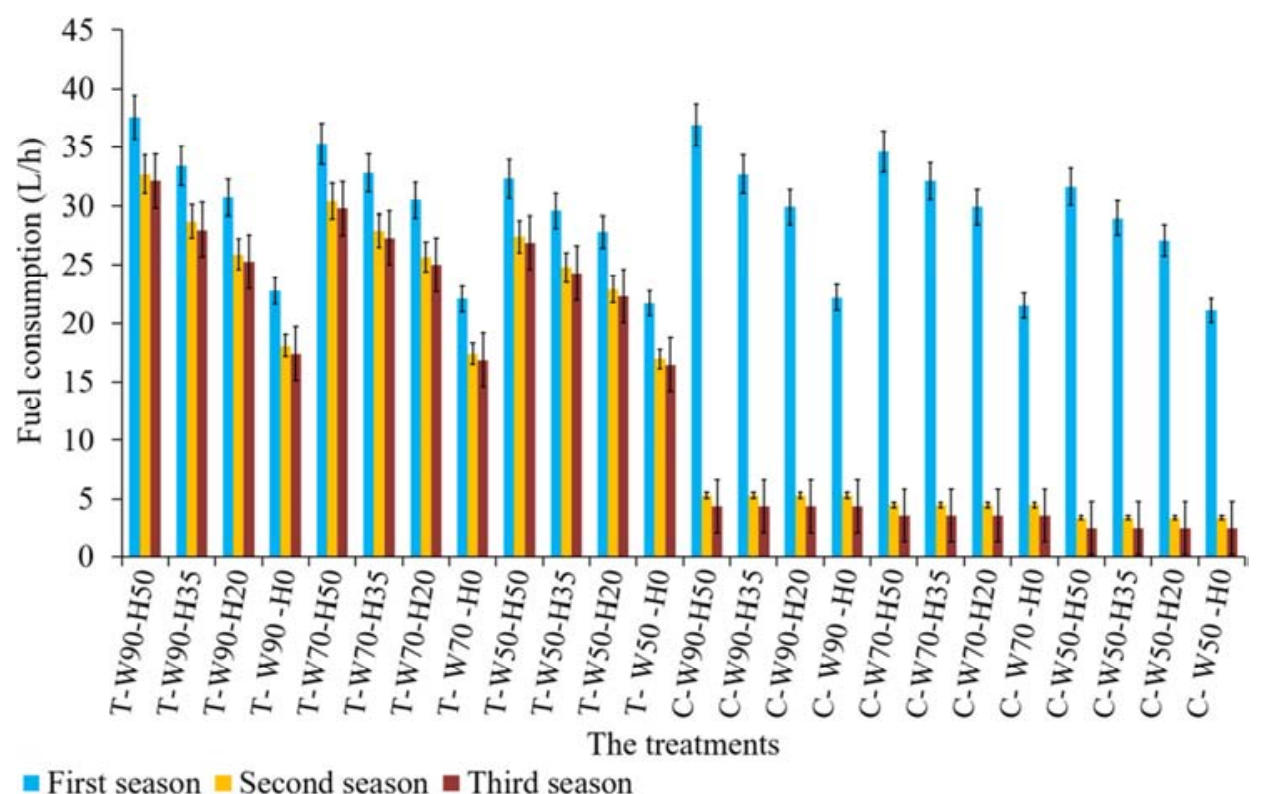

Figure 15. Effect of study treatments (T-traditional tillage, $C$-conservation tillage, $W$-ridge width at three levels (90cm, $70 \mathrm{~cm}$ and $50 \mathrm{~cm})$ and $H$ - ridge height at three levels $(50 \mathrm{~cm}, 35 \mathrm{~cm}, 20 \mathrm{~cm}$ and $0 \mathrm{~cm}))$ on fuel consumption. Bars represent $S E s,(P>0.05)$.

\subsection{Soil Bulk Density, Average Infiltration Rate and Soil Salinity}

The data presented in Table 7 and Figure 16 indicated that the soil bulk density decreased about $14 \%$ in the traditional tillage system compared to the conservation tillage system.

The results showed that increasing the dimensions of ridge cross section area (width and height) decreased the soil bulk density. Increasing ridge width from $50 \mathrm{~cm}$ to $90 \mathrm{~cm}$ and the ridge height from $20 \mathrm{~cm}$ to $50 \mathrm{~cm}$ led to decrease in soil bulk density about $6 \%$ and $7 \%$ respectively. This result may be attributed to that reduce the dimensions of ridges cross section area caused increasing the pressure force of machine on the soil during ridge construction process, therefore soil bulk density increased.

In general, when the number of seasons increased, the soil bulk density decreased. Soil bulk density decreased about $8 \%$ in the third season compared to the first season. This result may be attributed to that sustainable of the conservation tillage system reduced soil bulk density of the ridges due to increase dissolution of the previous crop residues by microorganism's activity in the soil and soil moisture content, which increases soil aggregate.

Results in Table 7 and Figure 17 cleared that average infiltration rate increased in traditional tillage system about of $43 \%$ compared to conservation tillage system. Increasing both of ridges width from $50 \mathrm{~cm}$ to $90 \mathrm{~cm}$ and ridges height from $20 \mathrm{~cm}$ to $50 \mathrm{~cm}$ caused increasing average infiltration rate about $12 \%$ and $13 \%$ respectively. At the third season, average infiltration rate increased about $21 \%$ compared to the first season.

Results in Table 8 and Figure 18 showed that a significant effect of study treatments on soil salinity. Soil salinity decreased with ridge wide $90 \mathrm{~cm}$, ridge height $50 \mathrm{~cm}$, conservation tillage system and third season about $2 \%, 18 \%$, $7 \%$ and $7 \%$ respectively, compared to ridge width $50 \mathrm{~cm}$, ridge height $0 \mathrm{~cm}$ (flat soil), traditional tillage system and first season. These results may be the fact that when cross section of ridges (width $\mathrm{x}$ height) increases the size of ridges increases subsequently, water stored in ridges increased with easy drainage of irrigation water from the ridge to the furrows which caused leaching saline from soil, in addition conservation tillage (no-tillage) which causes covered of the soil surface by the residues of previous crops, which increases soil moisture retention and decreases the level of soil salinity.

The results showed that soil salinity decreased about $13 \%$ when using wide ridge system (raised-bed soil) system compared to flat soil. This result may be the fact that in raised-bed system the soil ability of stored water increases and easy drainage this water to adjacent furrows so that soil salinity decreased.

\subsection{Water Stored in the Effective Root Zone and Water Consumption Use in Root Zone}

The data in Table 9 and Figures 19 and 20 proved that water stored in the effective root zone (WS) and water consumption use in root zone (WCU) increased in conservation tillage system about $8 \%$ and $8 \%$ respectively, compared to traditional tillage system. These results may be explained that the conservation tillage system, plant residues on the soil surface reduced irrigation water evaporation.

Results indicated to, when ridges width increased from $50 \mathrm{~cm}$ to $90 \mathrm{~cm}$ the (WS) and (WCU) increased about $12 \%$ and $18 \%$ respectively, also increasing in ridges height from zero $\mathrm{cm}$ (flat soil) to $50 \mathrm{~cm}$ the (WS) and (WCU) increased about $36 \%$ and $49 \%$ respectively. In general, the sequence of season led to an increasing in (WS) and (WCU) about of $9 \%$ and $14 \%$ respectively, in the third season compared to the first season.

Results showed that the (WS) and (WCU) increased about 
$27 \%$ and $36 \%$ respectively, when using raised-bed system compared to flat soil.

Table 7. Effect of study treatments on soil bulk density and average infiltration rate.

\begin{tabular}{|c|c|c|c|c|c|c|c|c|c|}
\hline \multirow{2}{*}{$\begin{array}{l}\text { Tillage } \\
\text { system }\end{array}$} & \multicolumn{3}{|c|}{ Ridge dimensions (cm) } & \multicolumn{3}{|c|}{ Soil bulk density $\left(\mathrm{g} / \mathrm{cm}^{3}\right)$} & \multicolumn{3}{|c|}{ Average infiltration rate $(\mathrm{L} / \mathrm{h})$} \\
\hline & Width & Height & & First season & Second season & Third season & First season & Second season & Third season \\
\hline \multirow{12}{*}{$\begin{array}{l}\text { Traditional } \\
\text { tillage }\end{array}$} & \multirow{4}{*}{90} & \multirow{3}{*}{$\begin{array}{l}\text { Raised } \\
\text { soil }\end{array}$} & 50 & $1.28 \mathrm{C}$ & $1.25 \mathrm{D}$ & $1.23 \mathrm{E}$ & $12.3 \mathrm{~lm}$ & $12.6 \mathrm{k}$ & $12.9 \mathrm{j}$ \\
\hline & & & 35 & $1.35 \mathrm{xy}$ & $1.31 \mathrm{zA}$ & $1.28 \mathrm{C}$ & $11.5 \mathrm{op}$ & $12.1 \mathrm{~m}$ & $12.5 \mathrm{kl}$ \\
\hline & & & 20 & $1.4 \mathrm{st}$ & $1.37 \mathrm{vm}$ & $1.34 \mathrm{y}$ & $10.8 \mathrm{st}$ & $11.2 \mathrm{q}$ & 11.6 no \\
\hline & & Flat soil & 0 & $1.2 \mathrm{G}$ & $1.15 \mathrm{~J}$ & $1.1 \mathrm{~L}$ & $13.6 \mathrm{fg}$ & $14.1 \mathrm{~cd}$ & $14.5 \mathrm{a}$ \\
\hline & \multirow{4}{*}{70} & \multirow{3}{*}{$\begin{array}{l}\text { Raised } \\
\text { soil }\end{array}$} & 50 & $1.35 \mathrm{xy}$ & $1.32 \mathrm{z}$ & $1.29 \mathrm{BC}$ & $11.3 \mathrm{pq}$ & $11.8 \mathrm{n}$ & $12.3 \mathrm{~lm}$ \\
\hline & & & 35 & $1.41 \mathrm{rs}$ & $1.38 \mathrm{uv}$ & $1.36 \mathrm{wx}$ & 10.6 tuv & $11.1 \mathrm{qr}$ & $11.5 \mathrm{op}$ \\
\hline & & & 20 & $1.48 \mathrm{o}$ & $1.45 \mathrm{p}$ & $1.42 \mathrm{qr}$ & $9.8 \mathrm{~A}$ & 10.3 wxy & 10.6 tuv \\
\hline & & Flat soil & 0 & $1.21 \mathrm{FG}$ & $1.16 \mathrm{IJ}$ & $1.11 \mathrm{KL}$ & $13.4 \mathrm{gh}$ & $13.9 \mathrm{de}$ & $14.4 \mathrm{ab}$ \\
\hline & \multirow{4}{*}{50} & \multirow{3}{*}{$\begin{array}{l}\text { Raised } \\
\text { soil }\end{array}$} & 50 & $1.41 \mathrm{rs}$ & $1.39 \mathrm{tu}$ & $1.36 \mathrm{wx}$ & $10.7 \mathrm{stu}$ & $11.1 \mathrm{qr}$ & 11.6 no \\
\hline & & & 35 & 1.48 o & $1.45 \mathrm{p}$ & $1.42 \mathrm{qr}$ & $10.1 \mathrm{yz}$ & $10.5 \mathrm{uvw}$ & 10.9 rs \\
\hline & & & 20 & $1.53 \mathrm{~m}$ & $1.51 \mathrm{n}$ & $1.49 \mathrm{o}$ & $9.5 \mathrm{~B}$ & $9.8 \mathrm{~A}$ & $10.2 \mathrm{xy}$ \\
\hline & & Flat soil & 0 & $1.22 \mathrm{EF}$ & $1.17 \mathrm{HI}$ & $1.12 \mathrm{~K}$ & $13.1 \mathrm{ij}$ & 13.7 ef & $14.2 \mathrm{bc}$ \\
\hline \multirow{12}{*}{$\begin{array}{l}\text { Conservation } \\
\text { tillage }\end{array}$} & \multirow{4}{*}{90} & \multirow{3}{*}{$\begin{array}{l}\text { Raised } \\
\text { soil }\end{array}$} & 50 & $1.26 \mathrm{D}$ & 1.551 & $1.51 \mathrm{n}$ & $12.5 \mathrm{kl}$ & $7.6 \mathrm{D}$ & $8.2 \mathrm{C}$ \\
\hline & & & 35 & $1.3 \mathrm{AB}$ & $1.6 \mathrm{jk}$ & 1.551 & 11.7 no & $7.3 \mathrm{E}$ & $7.7 \mathrm{D}$ \\
\hline & & & 20 & $1.38 \mathrm{uv}$ & $1.66 \mathrm{fg}$ & $1.61 \mathrm{j}$ & $11.1 \mathrm{qr}$ & $6.7 \mathrm{~F}$ & $7.2 \mathrm{E}$ \\
\hline & & Flat soil & 0 & $1.18 \mathrm{H}$ & $1.69 \mathrm{~cd}$ & $1.66 \mathrm{fg}$ & $13.4 \mathrm{gh}$ & $6.1 \mathrm{JK}$ & $6.5 \mathrm{FGH}$ \\
\hline & \multirow{4}{*}{70} & \multirow{3}{*}{$\begin{array}{l}\text { Raised } \\
\text { soil }\end{array}$} & 50 & $1.34 \mathrm{y}$ & $1.61 \mathrm{j}$ & 1.561 & 11.6 no & $6.7 \mathrm{~F}$ & $7.3 \mathrm{E}$ \\
\hline & & & 35 & $1.39 \mathrm{tu}$ & $1.65 \mathrm{gh}$ & $1.61 \mathrm{j}$ & $11.1 \mathrm{qr}$ & $6.4 \mathrm{GHI}$ & $7.1 \mathrm{E}$ \\
\hline & & & 20 & $1.43 \mathrm{q}$ & $1.68 \mathrm{de}$ & $1.64 \mathrm{hi}$ & $10.5 \mathrm{uvw}$ & $6.2 \mathrm{IJ}$ & $6.4 \mathrm{GHI}$ \\
\hline & & Flat soil & 0 & $1.2 \mathrm{G}$ & $1.7 \mathrm{bc}$ & $1.67 \mathrm{ef}$ & $13.3 \mathrm{hi}$ & $5.8 \mathrm{LM}$ & $6.3 \mathrm{HIJ}$ \\
\hline & \multirow{4}{*}{50} & \multirow{3}{*}{$\begin{array}{l}\text { Raised } \\
\text { soil }\end{array}$} & 50 & $1.4 \mathrm{st}$ & $1.63 \mathrm{i}$ & $1.59 \mathrm{k}$ & $10.9 \mathrm{rs}$ & $6.4 \mathrm{GHI}$ & $6.6 \mathrm{FG}$ \\
\hline & & & 35 & $1.46 \mathrm{p}$ & $1.68 \mathrm{de}$ & $1.64 \mathrm{hi}$ & 10.4 vwx & $5.9 \mathrm{KL}$ & $6.3 \mathrm{HIJ}$ \\
\hline & & & 20 & $1.51 \mathrm{n}$ & $1.71 \mathrm{ab}$ & $1.67 \mathrm{ef}$ & $9.9 \mathrm{zA}$ & $5.2 \mathrm{~N}$ & $5.7 \mathrm{LM}$ \\
\hline & & Flat soil & 0 & $1.21 \mathrm{FG}$ & $1.72 \mathrm{a}$ & $1.69 \mathrm{~cd}$ & $13.1 \mathrm{ij}$ & $5.6 \mathrm{M}$ & $6.1 \mathrm{JK}$ \\
\hline \multicolumn{4}{|c|}{ L. S. D at level 0.05} & 0.01958 & & & 0.2443 & & \\
\hline
\end{tabular}

Values accompanied by the same letter in each row are not significantly different $(\mathrm{P}>0.05)$ using Duncan's multiple range test.

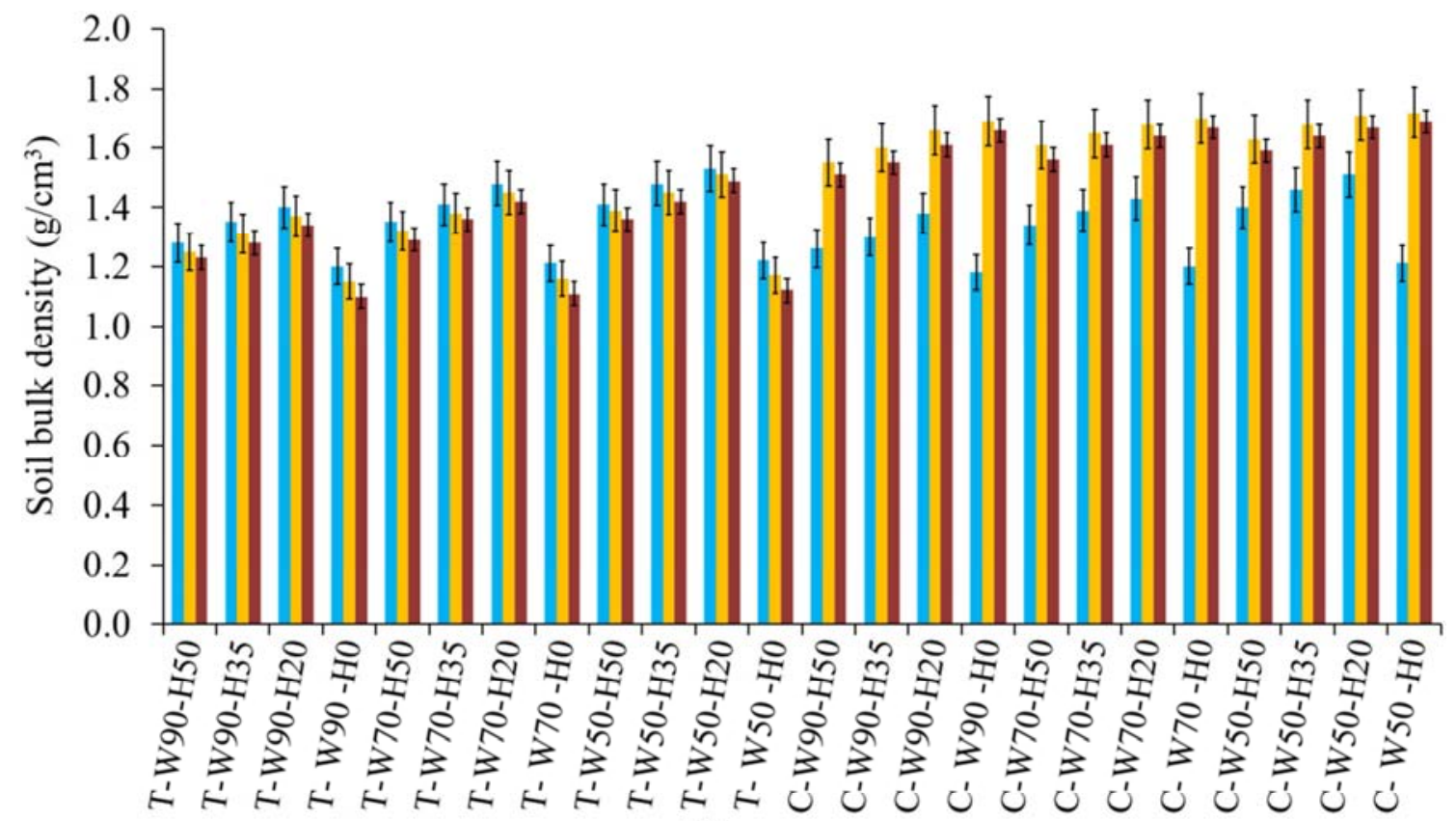

The treatments

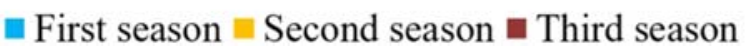

Figure 16. Effect of study treatments (T-traditional tillage, $C$-conservation tillage, $W$-ridge width at three levels (90cm, $70 \mathrm{~cm}$ and $50 \mathrm{~cm})$ and $H$-ridge height at three levels $(50 \mathrm{~cm}, 35 \mathrm{~cm}, 20 \mathrm{~cm}$ and $0 \mathrm{~cm}))$ on soil bulk density. Bars represent $S E S,(P>0.05)$. 


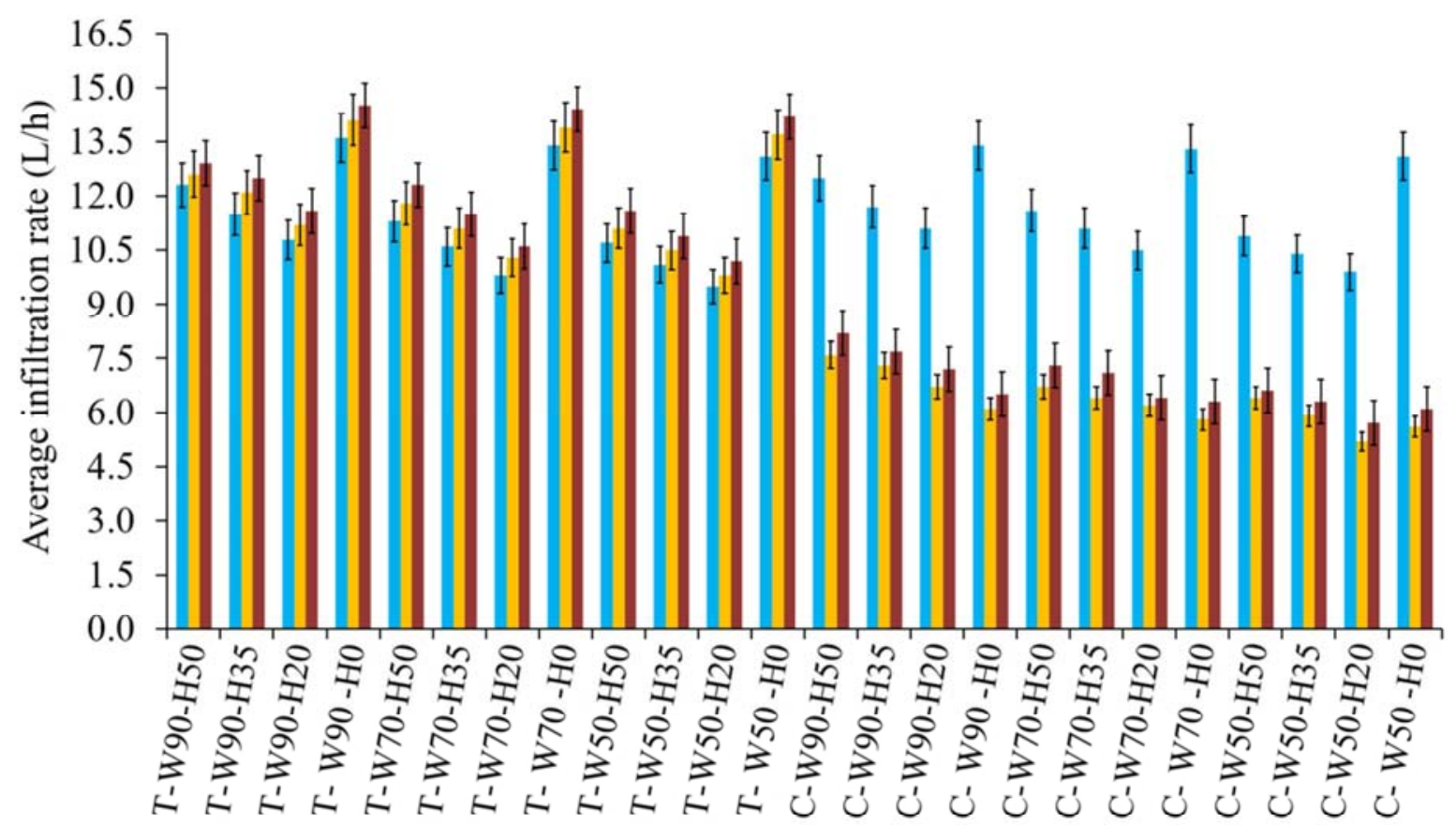

The treatments

\section{$\square$ First season $\approx$ Second season $\square$ Third season}

Figure 17. Effect of study treatments on (T-traditional tillage, C-conservation tillage, W-ridge width at three levels $(90 \mathrm{~cm}, 70 \mathrm{~cm}$ and $50 \mathrm{~cm})$ and $H$ - ridge height at three levels $(50 \mathrm{~cm}, 35 \mathrm{~cm}, 20 \mathrm{~cm}$ and $0 \mathrm{~cm}))$ average infiltration rate. Bars represent $S E s,(P>0.05)$.

Table 8. Effect of study treatments on soil salinity.

\begin{tabular}{|c|c|c|c|c|c|c|}
\hline \multirow{2}{*}{ Tillage system } & \multicolumn{3}{|c|}{ Ridge dimensions (cm) } & \multicolumn{3}{|c|}{ Soil salinity (ds/m) } \\
\hline & Width & Height & & First season & Second season & Third season \\
\hline \multirow{10}{*}{$\begin{array}{l}\text { Traditional } \\
\text { tillage }\end{array}$} & \multirow{3}{*}{90} & \multirow{2}{*}{ Raised soil } & 50 & 7.38 opqr & $7.33 \mathrm{pqr}$ & $7.27 \mathrm{qr}$ \\
\hline & & & 20 & $8.51 \mathrm{def}$ & 8.46 ef & $8.41 \mathrm{fg}$ \\
\hline & & \multirow[t]{2}{*}{ Flat soil } & 0 & $9.11 \mathrm{a}$ & $8.92 \mathrm{bc}$ & $8.85 \mathrm{c}$ \\
\hline & \multirow{4}{*}{70} & & 50 & $7.41 \mathrm{opq}$ & $7.35 \mathrm{pqr}$ & $7.28 \mathrm{qr}$ \\
\hline & & \multirow[t]{2}{*}{ Raised soil } & 35 & $7.98 \mathrm{k}$ & $7.93 \mathrm{k}$ & $7.88 \mathrm{kl}$ \\
\hline & & & 20 & 8.56 de & $8.51 \mathrm{def}$ & 8.46 ef \\
\hline & & \multirow[t]{2}{*}{ Flat soil } & 0 & $9.15 \mathrm{a}$ & $8.98 \mathrm{~b}$ & $8.91 \mathrm{bc}$ \\
\hline & \multirow{3}{*}{50} & & 50 & $7.55 \mathrm{n}$ & 7.49 no & $7.36 \mathrm{pqr}$ \\
\hline & & \multirow[t]{2}{*}{ Raised soil } & 35 & $8.13 \mathrm{j}$ & $7.95 \mathrm{k}$ & $7.89 \mathrm{kl}$ \\
\hline & & & 20 & $8.61 \mathrm{~d}$ & $8.57 \mathrm{de}$ & $8.5 \mathrm{def}$ \\
\hline \multirow{12}{*}{$\begin{array}{l}\text { Conservation } \\
\text { tillage }\end{array}$} & \multirow{4}{*}{90} & \multirow{3}{*}{ Raised soil } & 50 & $7.28 \mathrm{qr}$ & $6.62 \mathrm{v}$ & $6.17 x$ \\
\hline & & & 35 & $7.71 \mathrm{~m}$ & $7.28 \mathrm{qr}$ & $6.78 \mathrm{tu}$ \\
\hline & & & 20 & $8.32 \mathrm{gh}$ & $7.87 \mathrm{kl}$ & 7.37 opqr \\
\hline & & \multirow[t]{2}{*}{ Flat soil } & 0 & $8.92 \mathrm{bc}$ & $8.51 \mathrm{def}$ & $8.16 \mathrm{ij}$ \\
\hline & \multirow{4}{*}{70} & & 50 & $7.25 \mathrm{r}$ & $6.71 \mathrm{u}$ & $6.25 \mathrm{wx}$ \\
\hline & & \multirow[t]{2}{*}{ Raised soil } & 35 & $7.76 \mathrm{~lm}$ & $7.31 \mathrm{pqr}$ & $6.83 \mathrm{t}$ \\
\hline & & & 20 & $8.31 \mathrm{gh}$ & $7.87 \mathrm{kl}$ & 7.49 no \\
\hline & & \multirow[t]{2}{*}{ Flat soil } & 0 & $8.98 \mathrm{~b}$ & $8.57 \mathrm{de}$ & $8.21 \mathrm{hij}$ \\
\hline & \multirow{4}{*}{50} & & 50 & $7.31 \mathrm{pqr}$ & $6.88 \mathrm{t}$ & $6.31 \mathrm{w}$ \\
\hline & & \multirow[t]{2}{*}{ Raised soil } & 35 & $7.86 \mathrm{kl}$ & 7.43 op & $6.97 \mathrm{~s}$ \\
\hline & & & 20 & $8.53 \mathrm{def}$ & $7.95 \mathrm{k}$ & $7.56 \mathrm{n}$ \\
\hline & & Flat soil & 0 & $9.14 \mathrm{a}$ & $8.62 \mathrm{~d}$ & $8.26 \mathrm{hi}$ \\
\hline
\end{tabular}

Values accompanied by the same letter in each row are not significantly different $(\mathrm{P}>0.05)$ using Duncan's multiple range test. 


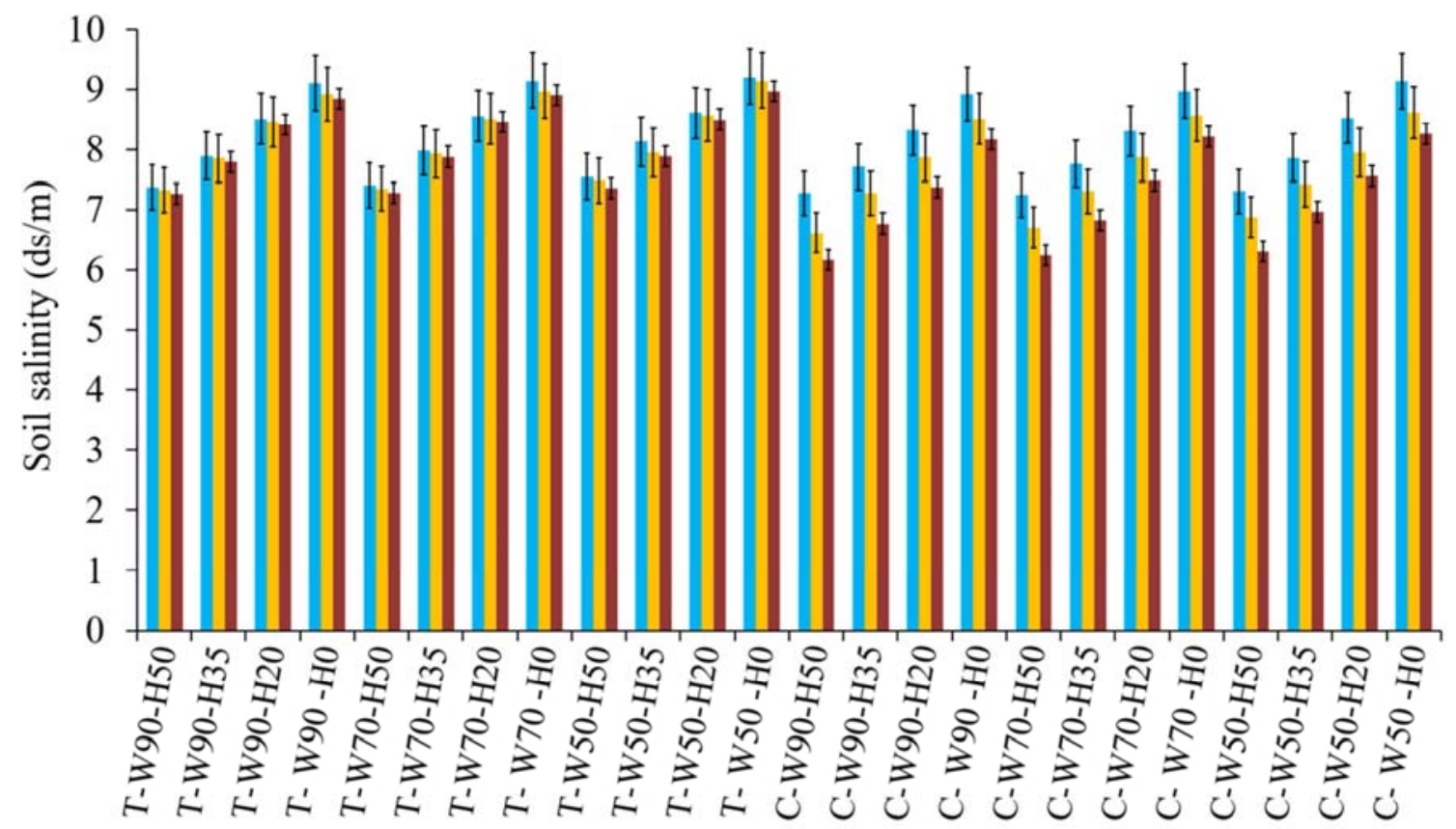

The treatments

m First season $\|$ Second season $\|$ Third season

Figure 18. Effect of study treatments on (T-traditional tillage, $C$-conservation tillage, $W$-ridge width at three levels (90cm, $70 \mathrm{~cm}$ and $50 \mathrm{~cm})$ and $H$-ridge height at three levels $(50 \mathrm{~cm}, 35 \mathrm{~cm}, 20 \mathrm{~cm}$ and $0 \mathrm{~cm}))$ soil salinity. Bars represent $S E s,(P>0.05)$.

Table 9. Effect of study treatments on water stored in effective root zone and water consumptive use in root zone.

\begin{tabular}{|c|c|c|c|c|c|c|c|c|c|}
\hline \multirow{2}{*}{$\begin{array}{l}\text { Tillage } \\
\text { system }\end{array}$} & \multicolumn{3}{|c|}{ Ridge dimensions (cm) } & \multicolumn{3}{|c|}{ Water stored in the effective root zone $\left(\mathrm{m}^{3} / \mathrm{ha}\right)$} & \multicolumn{3}{|c|}{ Water consumptive use in root zone $\left(\mathrm{m}^{3} / \mathrm{ha}\right)$} \\
\hline & Width & Height & & First season & Second season & Third season & First season & Second season & Third season \\
\hline \multirow{12}{*}{$\begin{array}{l}\text { Traditional } \\
\text { tillage }\end{array}$} & \multirow{4}{*}{90} & \multirow{3}{*}{$\begin{array}{l}\text { Raised } \\
\text { soil }\end{array}$} & 50 & $5122 \mathrm{~h}$ & $5175 \mathrm{~g}$ & $5253 \mathrm{f}$ & $3974 \mathrm{ij}$ & $4098 \mathrm{f}$ & $4246 \mathrm{~d}$ \\
\hline & & & 35 & $4802 \mathrm{p}$ & $4876 \mathrm{mn}$ & $4947 \mathrm{k}$ & $3654 \mathrm{pq}$ & $3778 \mathrm{~m}$ & $3951 \mathrm{j}$ \\
\hline & & & 20 & 4485 uv & $4542 \mathrm{t}$ & $4600 \mathrm{~s}$ & 3337 wx & $3459 \mathrm{u}$ & 3606 rs \\
\hline & & Flat soil & 0 & $3576 \mathrm{G}$ & $3640 \mathrm{~F}$ & $3705 \mathrm{E}$ & $2514 \mathrm{~N}$ & $2663 \mathrm{~K}$ & $2564 \mathrm{M}$ \\
\hline & \multirow{4}{*}{70} & \multirow{3}{*}{$\begin{array}{l}\text { Raised } \\
\text { soil }\end{array}$} & 50 & $4876 \mathrm{mn}$ & $4945 \mathrm{k}$ & $5014 \mathrm{j}$ & 3705 no & $3804 \mathrm{~lm}$ & $3901 \mathrm{k}$ \\
\hline & & & 35 & $4478 \mathrm{uv}$ & $4535 \mathrm{t}$ & $4611 \mathrm{~s}$ & $3335 w x$ & $3459 \mathrm{u}$ & $3507 \mathrm{t}$ \\
\hline & & & 20 & $4137 \mathrm{z}$ & $4209 \mathrm{y}$ & $4278 \mathrm{x}$ & $2997 \mathrm{D}$ & $3188 \mathrm{~A}$ & $3238 \mathrm{yz}$ \\
\hline & & Flat soil & 0 & $3519 \mathrm{H}$ & $3583 \mathrm{G}$ & $3645 \mathrm{~F}$ & $2454 \mathrm{OP}$ & $2554 \mathrm{OP}$ & $2672 \mathrm{JK}$ \\
\hline & \multirow{4}{*}{50} & \multirow{3}{*}{$\begin{array}{l}\text { Raised } \\
\text { soil }\end{array}$} & 50 & $4462 \mathrm{v}$ & $4542 \mathrm{t}$ & $4600 \mathrm{~s}$ & $3312 \mathrm{x}$ & $3459 \mathrm{u}$ & $3581 \mathrm{~s}$ \\
\hline & & & 35 & $4137 \mathrm{z}$ & $4209 \mathrm{y}$ & $4282 \mathrm{x}$ & $2992 \mathrm{D}$ & $3139 \mathrm{~B}$ & 3213 zA \\
\hline & & & 20 & $3893 \mathrm{D}$ & $3965 \mathrm{C}$ & $4016 \mathrm{~B}$ & $2698 \mathrm{IJ}$ & $2845 \mathrm{G}$ & $2918 \mathrm{EF}$ \\
\hline & & Flat soil & 0 & $3450 \mathrm{I}$ & $3521 \mathrm{H}$ & $3585 \mathrm{G}$ & $2410 \mathrm{Q}$ & $2484 \mathrm{O}$ & $2606 \mathrm{~L}$ \\
\hline \multirow{12}{*}{$\begin{array}{l}\text { Conservation } \\
\text { tillage }\end{array}$} & \multirow{4}{*}{90} & \multirow{3}{*}{$\begin{array}{l}\text { Raised } \\
\text { soil }\end{array}$} & 50 & $5149 \mathrm{gh}$ & $5635 \mathrm{~b}$ & 5773 a & 4001 hi & $4565 \mathrm{~b}$ & $4834 \mathrm{a}$ \\
\hline & & & 35 & 4828 op & $5244 \mathrm{f}$ & $5439 d$ & 3682 op & $4220 \mathrm{de}$ & $4466 \mathrm{c}$ \\
\hline & & & 20 & 4512 tu & $4984 \mathrm{j}$ & $5177 \mathrm{~g}$ & $3362 \mathrm{w}$ & 38271 & $4048 \mathrm{~g}$ \\
\hline & & Flat soil & 0 & $3602 \mathrm{G}$ & $4013 \mathrm{~B}$ & $4137 \mathrm{z}$ & $2537 \mathrm{MN}$ & $2925 \mathrm{EF}$ & $3049 \mathrm{C}$ \\
\hline & \multirow{4}{*}{70} & \multirow{3}{*}{$\begin{array}{l}\text { Raised } \\
\text { soil }\end{array}$} & 50 & $4898 \mathrm{j}$ & 5370 e & $5566 \mathrm{c}$ & $3732 \mathrm{n}$ & 4197 e & $4441 \mathrm{c}$ \\
\hline & & & 35 & $4505 \mathrm{tu}$ & $5046 \mathrm{i}$ & $5244 \mathrm{f}$ & $3363 \mathrm{w}$ & $3778 \mathrm{~m}$ & $4025 \mathrm{gh}$ \\
\hline & & & 20 & $4162 \mathrm{z}$ & $4726 \mathrm{q}$ & 49121 & $3025 \mathrm{CD}$ & $3411 \mathrm{v}$ & $3631 \mathrm{qr}$ \\
\hline & & Flat soil & 0 & $3545 \mathrm{H}$ & $3956 \mathrm{C}$ & $4075 \mathrm{~A}$ & $2481 \mathrm{O}$ & $2801 \mathrm{H}$ & $2900 \mathrm{~F}$ \\
\hline & \multirow{4}{*}{50} & \multirow{3}{*}{$\begin{array}{l}\text { Raised } \\
\text { soil }\end{array}$} & 50 & 4484 uv & $4981 \mathrm{j}$ & $5175 \mathrm{~g}$ & 3338 wx & $3804 \mathrm{~lm}$ & $4048 \mathrm{~g}$ \\
\hline & & & 35 & $4165 \mathrm{z}$ & $4669 \mathrm{r}$ & 4855 no & $3020 \mathrm{CD}$ & $3434 \mathrm{uv}$ & 3680 op \\
\hline & & & 20 & $3916 \mathrm{D}$ & $4335 \mathrm{w}$ & $4464 \mathrm{v}$ & 2724 I & $3040 \mathrm{C}$ & 3264 y \\
\hline & & Flat soil & 0 & 3477 I & $3889 \mathrm{D}$ & $4009 \mathrm{~B}$ & $2434 \mathrm{PQ}$ & $2781 \mathrm{H}$ & $2951 \mathrm{E}$ \\
\hline \multicolumn{4}{|c|}{ L. S. D at level 0.05} & \multicolumn{3}{|l|}{27.79} & \multicolumn{3}{|l|}{27.47} \\
\hline
\end{tabular}

Values accompanied by the same letter in each row are not significantly different $(\mathrm{P}>0.05)$ using Duncan's multiple range test. 


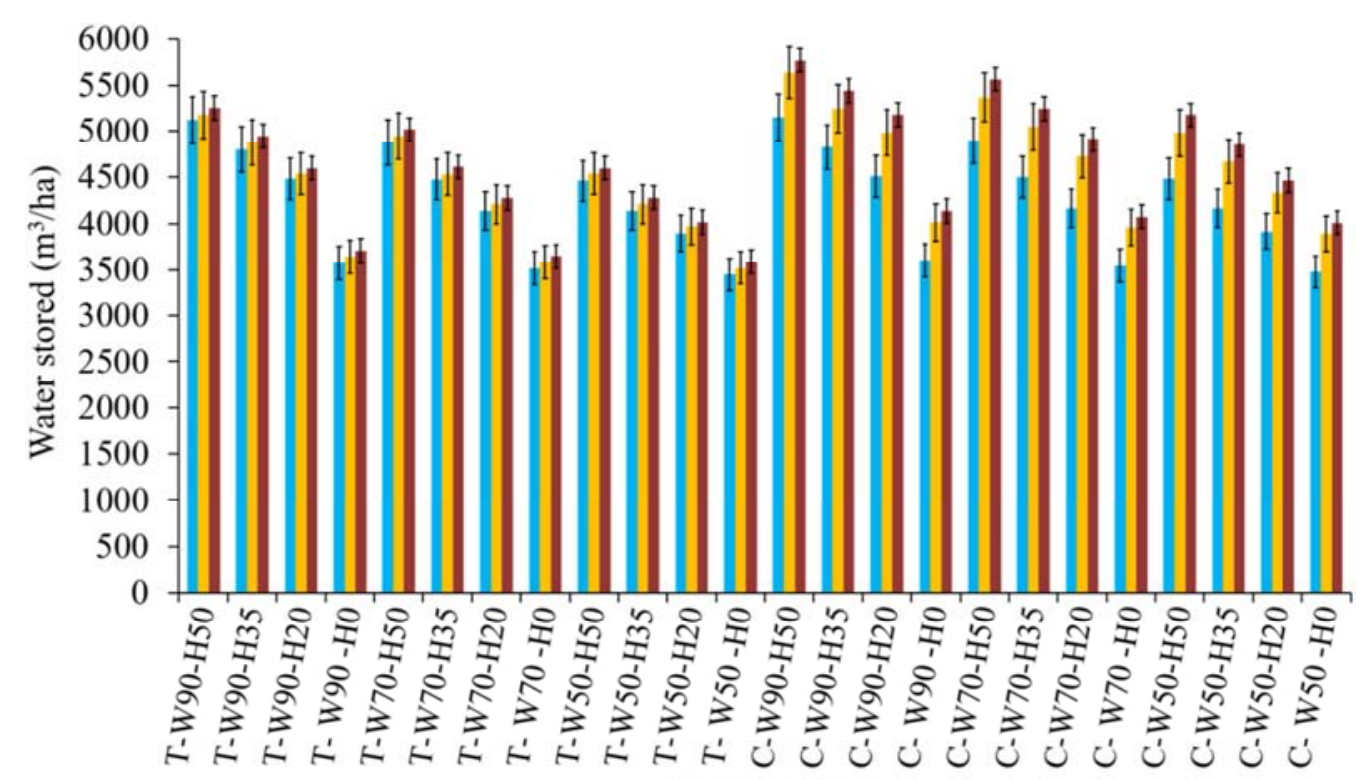

a First season $\mathbf{m}$ Second season $\mathbf{m}$ Third season

Figure 19. Effect of study treatments (T-traditional tillage, $C$-conservation tillage, $W$-ridge width at three levels (90cm, $70 \mathrm{~cm}$ and $50 \mathrm{~cm}$ ) and $H$-ridge height at three levels $(50 \mathrm{~cm}, 35 \mathrm{~cm}, 20 \mathrm{~cm}$ and $0 \mathrm{~cm}))$ on water stored in effective root zone. Bars represent $S E s,(P>0.05)$.

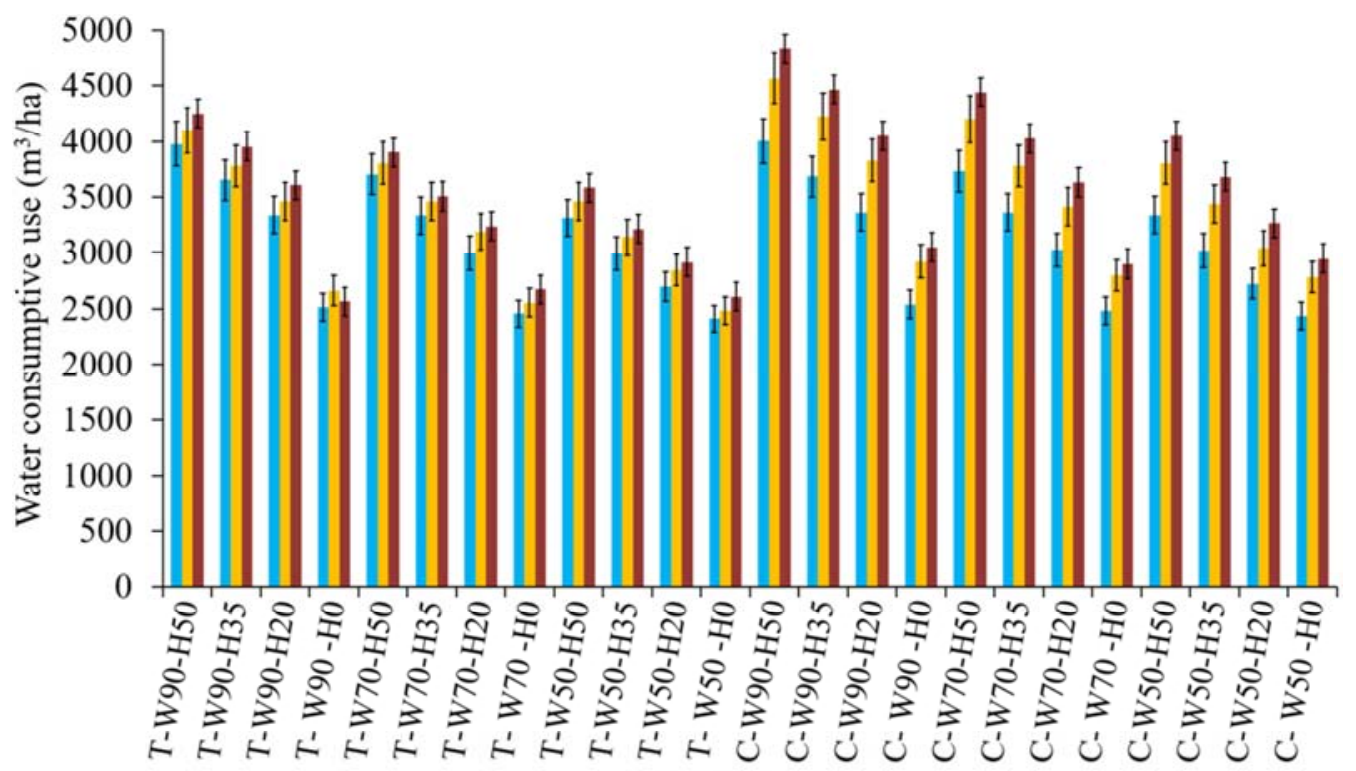

a First season $\mathbf{n}^{\mathrm{a}}$ Second season $\mathbf{m}$ Third season

Figure 20. Effect of study treatments (T-traditional tillage, $C$ - conservation tillage, $W$-ridge width at three levels (90cm, $70 \mathrm{~cm}$ and $50 \mathrm{~cm}$ ) and $H$-ridge height at three levels $(50 \mathrm{~cm}, 35 \mathrm{~cm}, 20 \mathrm{~cm}$ and $0 \mathrm{~cm}))$ on water consumptive use in root zone. Bars represent $S E s,(P>0.05)$.

\subsection{Wheat Grain Yield, Water Productivity, Water Application Efficiency and Specific Cost of Production}

Tables 10, 11 and Figures 21, 22, 23 and 24 illustrated that wheat grain yield, water productivity and water application efficiency increased in conservation tillage system about $19 \%$, $10 \%$ and $8 \%$ respectively, compared to traditional tillage system. However, the specific cost of production decreased with conservation tillage system about 39\% compared to traditional tillage system. The data indicated that increasing ridge width from $50 \mathrm{~cm}$ to $90 \mathrm{~cm}$ the wheat grain yield, water productivity and water application efficiency increased about $32 \%, 12 \%$ and $12 \%$ respectively and decreased specific cost of production about $52 \%$.

Also increasing ridge height from $0 \mathrm{~cm}$ (flat soil) to $50 \mathrm{~cm}$ the wheat grain yield, water productivity and water application efficiency increased about $92 \%, 28 \%$ and $36 \%$ respectively and decreased specific cost of production about of $29 \%$.

The data showed that third season achieved average increasing percentage in wheat grain yield, water productivity and water application efficiency about $26 \%, 10 \%$ and $9 \%$ 
respectively, and average decreasing percentage in specific cost of production about $40 \%$ compared to the first season.

Results showed that the wheat grain yield, water productivity and water application efficiency increased about
$66 \%, 19 \%$ and $27 \%$ respectively, and decreased specific cost of production about of $24 \%$ when using raised-bed system compared to flat soil.

Table 10. Effect of study treatments on wheat grain yield and water productivity.

\begin{tabular}{|c|c|c|c|c|c|c|c|c|c|}
\hline \multirow{2}{*}{$\begin{array}{l}\text { Tillage } \\
\text { system }\end{array}$} & \multicolumn{3}{|c|}{ Ridge dimensions (cm) } & \multicolumn{3}{|c|}{ Wheat grain yield (Mg/ha) } & \multicolumn{3}{|c|}{ Water productivity $\left(\mathrm{kg} / \mathrm{m}^{3}\right)$} \\
\hline & Width & Height & & First season & Second season & Third season & First season & Second season & Third season \\
\hline \multirow{11}{*}{$\begin{array}{l}\text { Traditional } \\
\text { tillage }\end{array}$} & \multirow{4}{*}{90} & \multirow{3}{*}{$\begin{array}{l}\text { Raised } \\
\text { soil }\end{array}$} & 50 & $6.3595 \mathrm{i}$ & $6.6401 \mathrm{~g}$ & $6.9621 \mathrm{f}$ & $1.60 \mathrm{defg}$ & $1.619 \mathrm{de}$ & $1.639 \mathrm{de}$ \\
\hline & & & 35 & $5.5177 \mathrm{n}$ & 5.78221 & $6.0858 \mathrm{j}$ & $1.501 \mathrm{kl}$ & $1.53 \mathrm{ijk}$ & 1.54 hijk \\
\hline & & & 20 & 4.7058 tuv & $4.9128 \mathrm{qrs}$ & $5.1566 \mathrm{o}$ & $1.41 \mathrm{opqr}$ & 1.42 mnopqr & $1.429 \mathrm{mnopq}$ \\
\hline & & Flat soil & 0 & $2.8359 \mathrm{HIJ}$ & $2.9854 \mathrm{GH}$ & $3.1625 \mathrm{~F}$ & $1.128 \mathrm{x}$ & $1.121 \mathrm{x}$ & $1.233 \mathrm{w}$ \\
\hline & \multirow{3}{*}{70} & \multirow{2}{*}{$\begin{array}{l}\text { Raised } \\
\text { soil }\end{array}$} & 50 & $5.5959 \mathrm{mn}$ & $5.8213 \mathrm{kl}$ & $6.0076 \mathrm{j}$ & $1.51 \mathrm{jkl}$ & $1.53 \mathrm{ijk}$ & 1.54 hijk \\
\hline & & & 20 & $3.956 \mathrm{zA}$ & $4.2711 \mathrm{wx}$ & $4.4045 \mathrm{w}$ & 1.32 tuv & 1.339 tuv & $1.36 \mathrm{stu}$ \\
\hline & & Flat soil & 0 & $2.7393 \mathrm{JK}$ & $2.8911 \mathrm{HIJ}$ & $3.0636 \mathrm{FG}$ & $1.116 \mathrm{x}$ & $1.132 \mathrm{x}$ & $1.146 \mathrm{x}$ \\
\hline & \multirow{4}{*}{50} & \multirow{3}{*}{$\begin{array}{l}\text { Raised } \\
\text { soil }\end{array}$} & 50 & $4.6368 \mathrm{uv}$ & $4.9128 \mathrm{qrs}$ & $5.1221 \mathrm{o}$ & 1.40 pqrs & 1.42 mnopqr & $1.43 \mathrm{mnopq}$ \\
\hline & & & 35 & $3.9192 \mathrm{~A}$ & 4.1446 xy & $4.2734 \mathrm{wx}$ & $1.31 \mathrm{uv}$ & 1.32 tuv & 1.33 tuv \\
\hline & & & 20 & $3.2913 \mathrm{E}$ & $3.5006 \mathrm{D}$ & $3.6478 \mathrm{C}$ & $1.22 \mathrm{w}$ & $1.23 \mathrm{w}$ & $1.249 \mathrm{w}$ \\
\hline & & Flat soil & 0 & $2.6519 \mathrm{~K}$ & $2.783 \mathrm{IJK}$ & $2.9716 \mathrm{GH}$ & $1.10 \mathrm{x}$ & $1.12 \mathrm{x}$ & $1.14 \mathrm{x}$ \\
\hline \multirow{11}{*}{$\begin{array}{l}\text { Conservation } \\
\text { tillage }\end{array}$} & \multirow{3}{*}{90} & \multirow{2}{*}{$\begin{array}{l}\text { Raised } \\
\text { soil }\end{array}$} & 50 & $6.451 \mathrm{hi}$ & $7.9442 \mathrm{~b}$ & $8.7032 \mathrm{a}$ & $1.612 \mathrm{def}$ & $1.74 \mathrm{~b}$ & $1.8 \mathrm{a}$ \\
\hline & & & 20 & $4.814 \mathrm{rst}$ & $5.9708 \mathrm{j}$ & $6.5182 \mathrm{gh}$ & $1.432 \mathrm{mnopq}$ & 1.56 ghij & $1.61 \mathrm{de}$ \\
\hline & & Flat soil & 0 & $2.924 \mathrm{GHI}$ & 3.9905 yzA & $4.577 \mathrm{v}$ & $1.15 \mathrm{x}$ & $1.364 \mathrm{st}$ & $1.5 \mathrm{kl}$ \\
\hline & \multirow{4}{*}{70} & \multirow{3}{*}{$\begin{array}{l}\text { Raised } \\
\text { soil }\end{array}$} & 50 & $5.607 \mathrm{mn}$ & $7.0932 \mathrm{e}$ & $7.8177 \mathrm{c}$ & $1.502 \mathrm{kl}$ & $1.69 \mathrm{c}$ & $1.76 \mathrm{~b}$ \\
\hline & & & 35 & $4.826 \mathrm{rst}$ & $6.0076 \mathrm{j}$ & $6.6424 \mathrm{~g}$ & $1.435 \mathrm{mnopq}$ & $1.589 \mathrm{efgh}$ & $1.65 \mathrm{~d}$ \\
\hline & & & 20 & $4.018 \mathrm{yzA}$ & $5.1175 \mathrm{o}$ & $5.7017 \mathrm{~lm}$ & 1.328 tuv & $1.5 \mathrm{kl}$ & 1.57 fghi \\
\hline & & Flat soil & 0 & 2.827 HIJ & $3.7996 \mathrm{~B}$ & $4.2619 \mathrm{wx}$ & $1.139 \mathrm{x}$ & $1.356 \mathrm{stu}$ & $1.469 \mathrm{lmn}$ \\
\hline & \multirow{4}{*}{50} & \multirow{3}{*}{$\begin{array}{l}\text { Raised } \\
\text { soil }\end{array}$} & 50 & 4.719 tuv & $5.934 \mathrm{jk}$ & $6.5987 \mathrm{~g}$ & 1.413 nopqr & 1.56 ghij & $1.63 \mathrm{de}$ \\
\hline & & & 35 & $4.107 \mathrm{xyz}$ & $5.0485 \mathrm{opq}$ & $5.704 \mathrm{~lm}$ & $1.359 \mathrm{stu}$ & $1.47 \mathrm{~lm}$ & 1.549 hijk \\
\hline & & & 20 & $3.316 \mathrm{E}$ & $4.2274 \mathrm{x}$ & $4.7656 \mathrm{stu}$ & $1.217 \mathrm{w}$ & $1.39 \mathrm{qrs}$ & 1.46 lmno \\
\hline & & Flat soil & 0 & $2.739 \mathrm{JK}$ & $3.6156 \mathrm{CD}$ & $4.0434 \mathrm{yzA}$ & $1.125 \mathrm{x}$ & $1.3 \mathrm{v}$ & $1.37 \mathrm{rst}$ \\
\hline \multicolumn{4}{|c|}{ L. S. D at level 0.05} & \multicolumn{3}{|l|}{0.1191} & \multicolumn{3}{|l|}{0.0331} \\
\hline
\end{tabular}

Values accompanied by the same letter in each row are not significantly different $(\mathrm{P}>0.05)$ using Duncan's multiple range test.

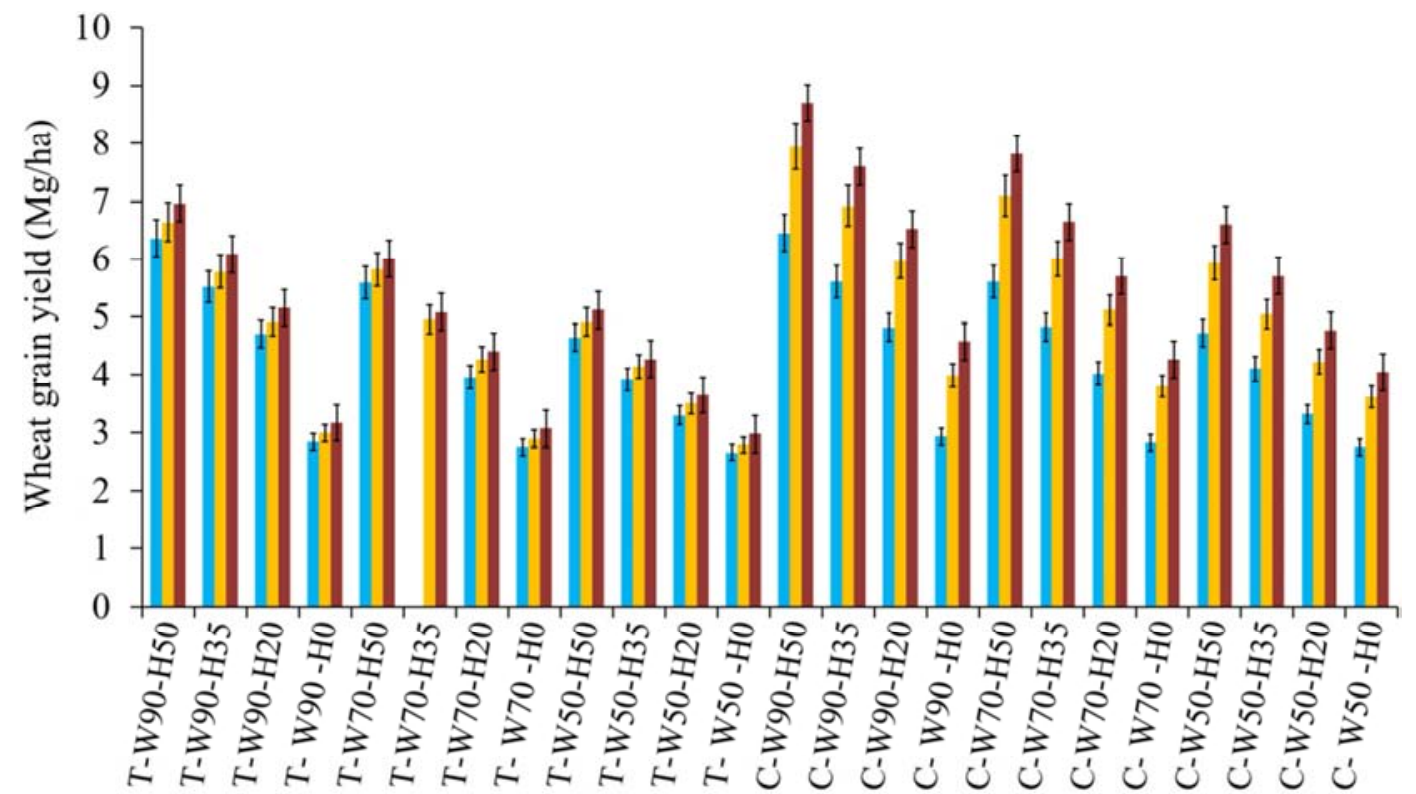

The treatments

$\approx$ First season $\approx$ Second season $\|$ Third season

Figure 21. Effect of study treatments (T-traditional tillage, $C$-conservation tillage, $W$-ridge width at three levels $(90 \mathrm{~cm}$, $70 \mathrm{~cm}$ and $50 \mathrm{~cm}$ ) and $H$-ridge height at three levels $(50 \mathrm{~cm}, 35 \mathrm{~cm}, 20 \mathrm{~cm}$ and $0 \mathrm{~cm}))$ on wheat grain yield. Bars represent $S E s,(P>0.05)$. 


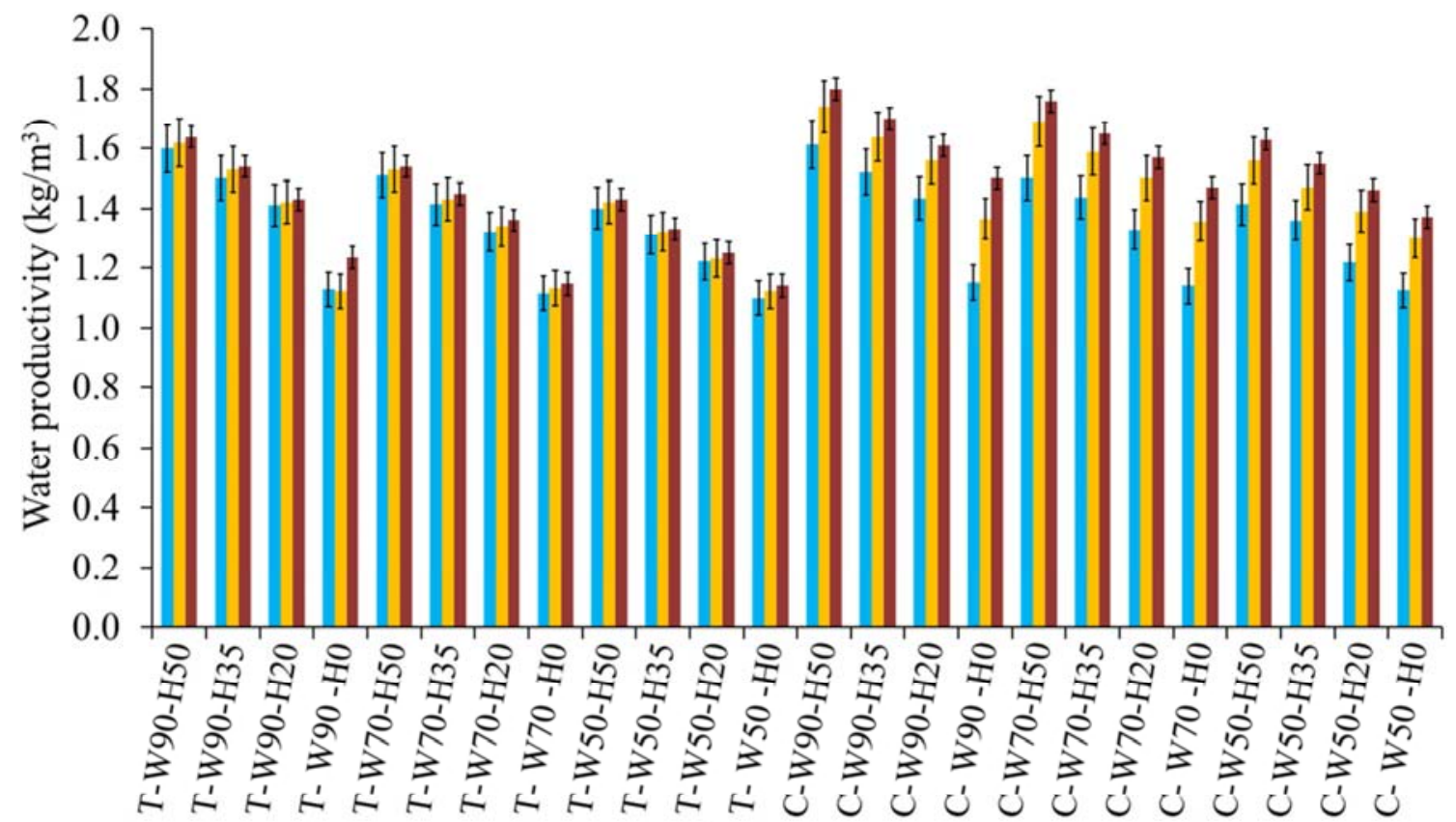

The treatments

a First season $\|$ Second season $\mathbf{m}$ Third season

Figure 22. Effect of study treatments (T-traditional tillage, C-conservation tillage, $W$-ridge width at three levels (90cm, $70 \mathrm{~cm}$ and $50 \mathrm{~cm})$ and $H$-ridge height at three levels $(50 \mathrm{~cm}, 35 \mathrm{~cm}, 20 \mathrm{~cm}$ and $0 \mathrm{~cm}))$ on water productivity. Bars represent $S E s,(P>0.05)$.

Table 11. Effect of study treatments on water application efficiency and specific cost of production

\begin{tabular}{|c|c|c|c|c|c|c|c|c|c|}
\hline \multirow{2}{*}{$\begin{array}{l}\text { Tillage } \\
\text { system }\end{array}$} & \multicolumn{3}{|c|}{ Ridge dimensions (cm) } & \multicolumn{2}{|c|}{ Water application efficiency (\%) } & \multicolumn{4}{|c|}{ Specific cost of production (L.E/Mg) } \\
\hline & Width & Height & & First season & Second season & Third season & First season & Second season & Third season \\
\hline \multirow{12}{*}{$\begin{array}{l}\text { Traditional } \\
\text { tillage }\end{array}$} & \multirow{4}{*}{90} & \multirow{3}{*}{$\begin{array}{l}\text { Raised } \\
\text { soil }\end{array}$} & 50 & $79.23 \mathrm{~h}$ & $80.1 \mathrm{~g}$ & $81.26 \mathrm{f}$ & 908 xyz & $840 \mathrm{zAB}$ & $761 \mathrm{BCD}$ \\
\hline & & & 35 & $74.3 \mathrm{o}$ & $75.43 \mathrm{~lm}$ & $76.53 \mathrm{k}$ & $960 \mathrm{wx}$ & 867 yzA & $766 \mathrm{BCD}$ \\
\hline & & & 20 & $69.4 \mathrm{uv}$ & $70.26 \mathrm{~s}$ & $71.2 \mathrm{r}$ & $1006 \mathrm{vw}$ & 927 wxy & $828 \mathrm{AB}$ \\
\hline & & Flat soil & 0 & $55.36 \mathrm{G}$ & $56.33 \mathrm{~F}$ & $57.3 \mathrm{E}$ & $1483 \mathrm{~lm}$ & 1316 o & $1210 \mathrm{pqr}$ \\
\hline & \multirow{4}{*}{70} & \multirow{3}{*}{$\begin{array}{l}\text { Raised } \\
\text { soil }\end{array}$} & 50 & $75.43 \mathrm{~lm}$ & $76.53 \mathrm{k}$ & $77.56 \mathrm{j}$ & 1274 op & $1191 \mathrm{qrs}$ & $1053 \mathrm{uv}$ \\
\hline & & & 35 & $69.3 \mathrm{uv}$ & $70.16 \mathrm{st}$ & $71.36 \mathrm{r}$ & 1317 o & $1219 \mathrm{pqr}$ & $1120 \mathrm{stu}$ \\
\hline & & & 20 & $64.03 \mathrm{z}$ & 65.13 y & $66.2 \times$ & $1430 \mathrm{mn}$ & 1279 op & 1173 rs \\
\hline & & Flat soil & 0 & $54.46 \mathrm{H}$ & $55.46 \mathrm{G}$ & $56.43 \mathrm{~F}$ & $1826 \mathrm{ghi}$ & $1638 \mathrm{jk}$ & 15071 \\
\hline & \multirow{4}{*}{50} & \multirow{3}{*}{$\begin{array}{l}\text { Raised } \\
\text { soil }\end{array}$} & 50 & $69.03 \mathrm{v}$ & $70.3 \mathrm{~s}$ & $71.2 \mathrm{r}$ & 1943 ef & $1810 \mathrm{hi}$ & $1599 \mathrm{k}$ \\
\hline & & & 35 & $64.03 \mathrm{z}$ & $65.13 \mathrm{y}$ & $66.23 \mathrm{x}$ & $2039 \mathrm{~d}$ & $1865 \mathrm{gh}$ & $1674 \mathrm{j}$ \\
\hline & & & 20 & $60.23 \mathrm{D}$ & $61.36 \mathrm{C}$ & $62.13 \mathrm{~B}$ & $2152 \mathrm{c}$ & 1950 ef & $1803 \mathrm{hi}$ \\
\hline & & Flat soil & 0 & 53.36 I & $54.46 \mathrm{H}$ & $55.5 \mathrm{G}$ & 2353 a & $2222 \mathrm{~b}$ & $2006 \mathrm{de}$ \\
\hline \multirow{12}{*}{$\begin{array}{l}\text { Conservation } \\
\text { tillage }\end{array}$} & \multirow{4}{*}{90} & \multirow{3}{*}{$\begin{array}{l}\text { Raised } \\
\text { soil }\end{array}$} & 50 & $79.66 \mathrm{gh}$ & $87.2 \mathrm{~b}$ & 89.33 a & 887 xyzA & $253 \mathrm{M}$ & $216 \mathrm{M}$ \\
\hline & & & 35 & 74.70 no & $81.13 \mathrm{f}$ & $84.13 \mathrm{~d}$ & 936 wxy & 290 LM & $248 \mathrm{M}$ \\
\hline & & & 20 & $69.83 \mathrm{stu}$ & $77.1 \mathrm{jk}$ & $80.1 \mathrm{~g}$ & 972 wx & $336 \mathrm{JKL}$ & $288 \mathrm{LM}$ \\
\hline & & Flat soil & 0 & $55.7 \mathrm{G}$ & $62.1 \mathrm{~B}$ & $64.03 \mathrm{z}$ & $1423 \mathrm{mn}$ & $504 \mathrm{GH}$ & $409 \mathrm{IJ}$ \\
\hline & \multirow{4}{*}{70} & \multirow{3}{*}{$\begin{array}{l}\text { Raised } \\
\text { soil }\end{array}$} & 50 & 75.761 & $83.06 \mathrm{e}$ & $86.13 \mathrm{c}$ & $1263 \mathrm{opq}$ & 384 IJK & $329 \mathrm{KL}$ \\
\hline & & & 35 & 69.66 tuv & $78.06 \mathrm{i}$ & $81.13 \mathrm{f}$ & 1278 op & $455 \mathrm{HI}$ & $386 \mathrm{JKL}$ \\
\hline & & & 20 & $64.43 \mathrm{z}$ & $73.13 \mathrm{p}$ & 761 & $1396 \mathrm{n}$ & $534 \mathrm{G}$ & $451 \mathrm{HI}$ \\
\hline & & Flat soil & 0 & $54.83 \mathrm{H}$ & $61.2 \mathrm{C}$ & $63.06 \mathrm{~A}$ & $1751 \mathrm{i}$ & $718 \mathrm{CDE}$ & $603 \mathrm{~F}$ \\
\hline & \multirow{4}{*}{50} & \multirow{3}{*}{$\begin{array}{l}\text { Raised } \\
\text { soil }\end{array}$} & 50 & $69.36 \mathrm{uv}$ & $77.1 \mathrm{jk}$ & $80.06 \mathrm{~g}$ & $1892 \mathrm{fg}$ & $669 \mathrm{E}$ & $702 \mathrm{DE}$ \\
\hline & & & 35 & $64.43 \mathrm{z}$ & $72.23 \mathrm{q}$ & $75.1 \mathrm{mn}$ & 1937 ef & $787 \mathrm{BC}$ & $812 \mathrm{AB}$ \\
\hline & & & 20 & $60.6 \mathrm{D}$ & $67.1 \mathrm{w}$ & $69.06 \mathrm{v}$ & $2114 \mathrm{c}$ & 938 wxy & $973 \mathrm{wx}$ \\
\hline & & Flat soil & 0 & $53.8 \mathrm{I}$ & $60.16 \mathrm{D}$ & $62.06 \mathrm{~B}$ & $2258 \mathrm{~b}$ & 1097 tu & $1145 \mathrm{rst}$ \\
\hline \multicolumn{4}{|c|}{ L. S. D at level 0.05} & \multicolumn{3}{|l|}{0.4337} & \multicolumn{3}{|l|}{57.22} \\
\hline
\end{tabular}

Values accompanied by the same letter in each row are not significantly different $(\mathrm{P}>0.05)$ using Duncan's multiple range test. 


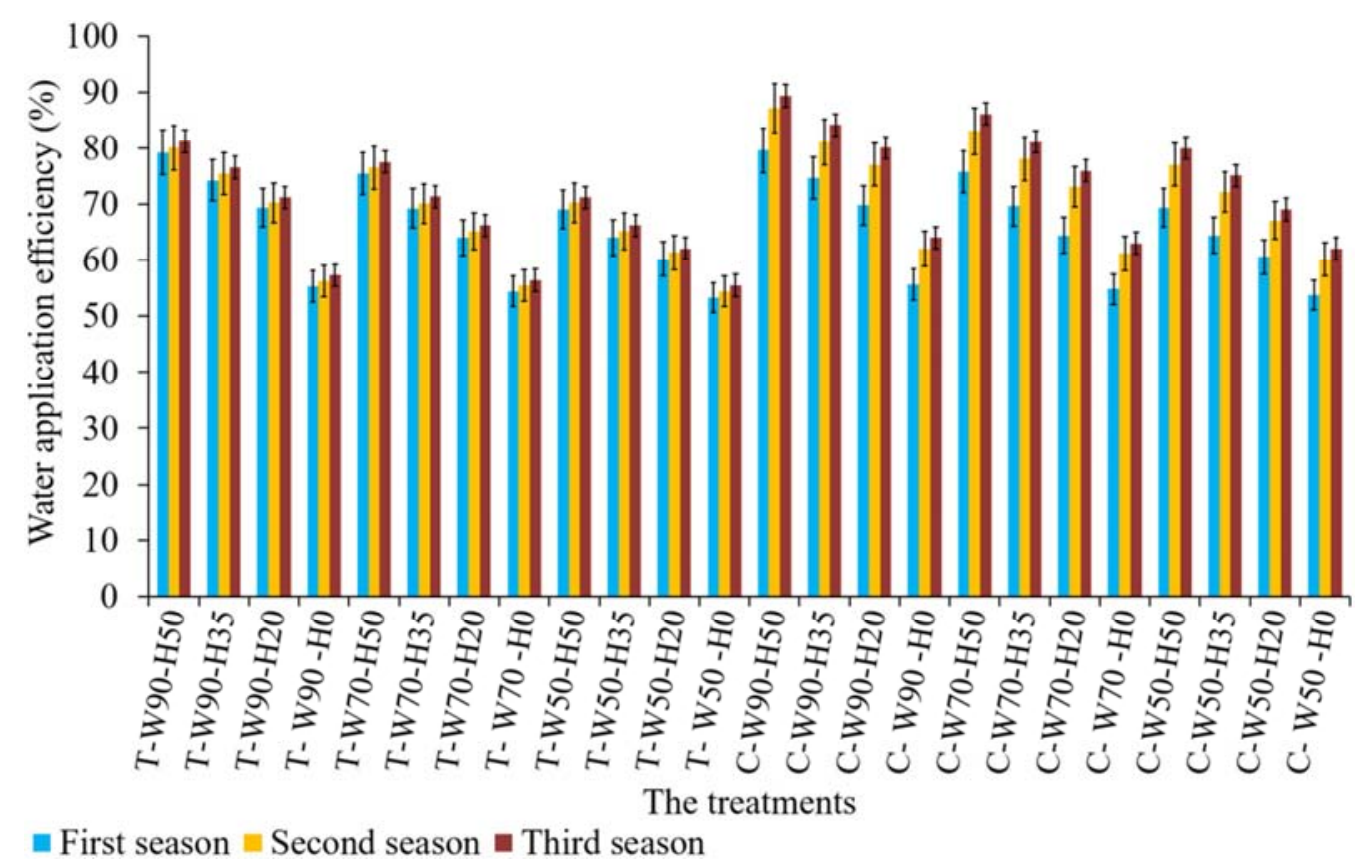

Figure 23. Effect of study treatments (T-traditional tillage, C-conservation tillage, $W$-ridge width at three levels (90cm, $70 \mathrm{~cm}$ and $50 \mathrm{~cm})$ and $H$ - ridge height at three levels $(50 \mathrm{~cm}, 35 \mathrm{~cm}, 20 \mathrm{~cm}$ and $0 \mathrm{~cm}))$ on water application efficiency. Bars represent $S E s,(P>0.05)$.

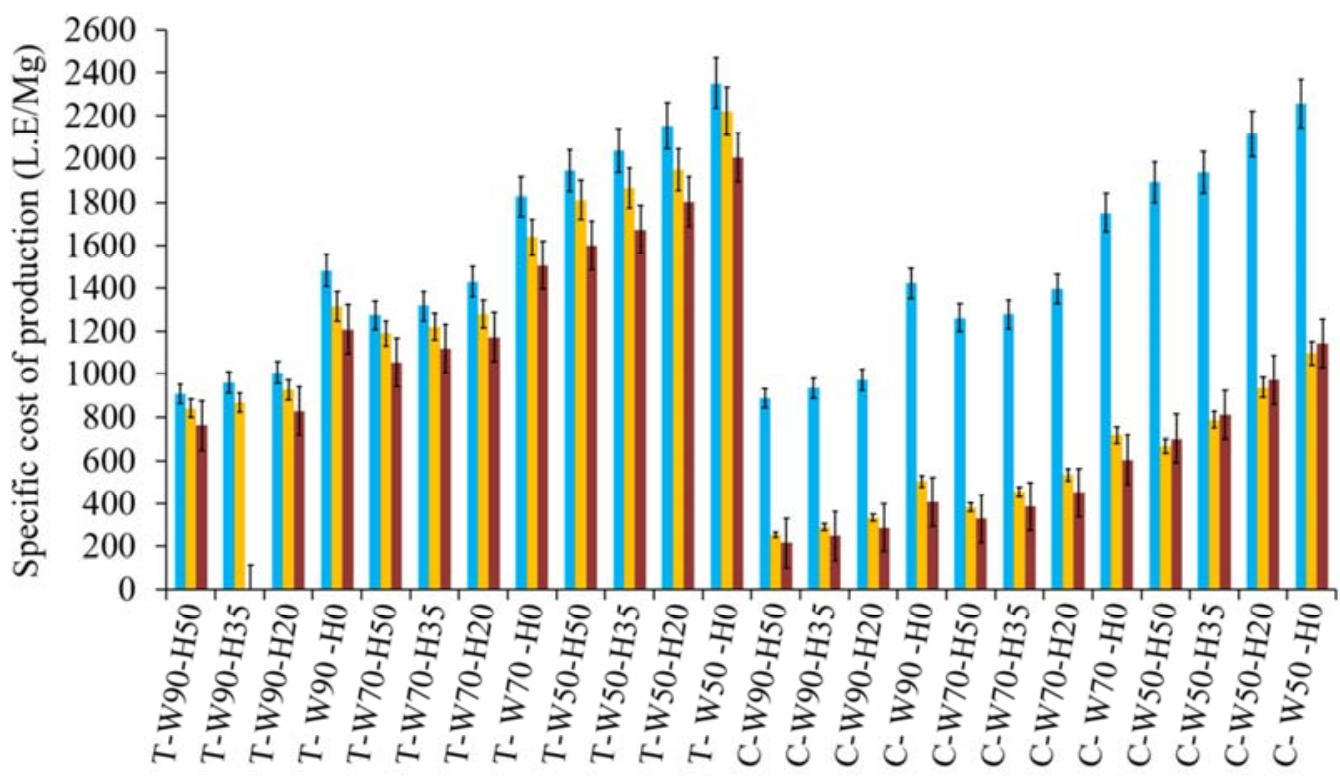

a First season $\|$ Second season $\|$ Third season

The treatments

Figure 24. Effect of study treatments (T-traditional tillage, C-conservation tillage, $W$-ridge width at three levels (90cm, $70 \mathrm{~cm}$ and $50 \mathrm{~cm})$ and $H$ - ridge height at three levels $(50 \mathrm{~cm}, 35 \mathrm{~cm}, 20 \mathrm{~cm}$ and $0 \mathrm{~cm}))$ on specific cost of production. Bars represent $S E s,(P>0.05)$.

\section{Conclusion}

The most important results of the study can be summarized in the following points:

1. The prototype of machine was successful in implementing the cultivation method of wide ridges (raised-bed soil) under traditional and conservation tillage systems.

2. The highest average increasing percentages in the actual field capacity and field efficiency of the machine were achieved at the ridge width $90 \mathrm{~cm}$, ridge height $0 \mathrm{~cm}$ (flat soil), conservation tillage system and the third season of field experiment application, were about $(79 \%, 11 \%, 49 \%$ and $60 \%)$ and $(10 \%, 13 \%, 10 \%$ and $25 \%)$ respectively, compared to the ridge width $50 \mathrm{~cm}$, ridge height $50 \mathrm{~cm}$, traditional tillage system and the first season.

3. The highest average decreasing percentages in the pulling force and fuel consumption rate were achieved at the ridge width $50 \mathrm{~cm}$, ridge height $0 \mathrm{~cm}$ (flat soil), conservation tillage system and the third season of field experiment application, were about $(3 \%, 40 \%, 52 \%$ and 
$50 \%)$ and $(14 \%, 37 \%, 53 \%$ and $53 \%)$ respectively, compared to the ridge width $90 \mathrm{~cm}$, ridge height $50 \mathrm{~cm}$, traditional tillage system and the first season.

4. The highest average decreasing percentages in soil bulk density was achieved at the ridge width $90 \mathrm{~cm}$, ridge height $50 \mathrm{~cm}$, traditional tillage system and the third season of field experiment application, were about $(6 \%$, $11 \%, 14 \%$ and $7 \%$ ) respectively, compared to the ridge width $50 \mathrm{~cm}$, ridge height $0 \mathrm{~cm}$ (flat soil), conservation tillage system and the first season.

5. The highest average increasing percentages in soil infiltration rate achieved at the ridge width $90 \mathrm{~cm}$, ridge height $50 \mathrm{~cm}$, traditional tillage system and the third season of field experiment application, were about (13\%, $24 \%, 43 \%$ and $21 \%$ ) respectively, compared to the ridge width $50 \mathrm{~cm}$, ridge height $0 \mathrm{~cm}$ (flat soil), conservation tillage system and the first season.

6. The highest average decreasing percentages in soil salinity was achieved at the ridge width $90 \mathrm{~cm}$, ridge height $50 \mathrm{~cm}$, conservation tillage system and the third season of field experiment application, were about $(2 \%$, $20 \%, 7 \%$ and $7 \%$ ) respectively, compared to the ridge width $50 \mathrm{~cm}$, ridge height $0 \mathrm{~cm}$ (flat soil), traditional tillage system and the first season.

7. The highest average increasing percentages in water stored in the effective root zone, water consumptive use in root zone and water application efficiency achieved at the ridge width $90 \mathrm{~cm}$, ridge height $50 \mathrm{~cm}$, conservation tillage system and the third season of field experiment application, were about $(12 \%, 36 \%, 8 \%$ and $9 \%),(18 \%, 49 \%, 8 \%$ and $14 \%)$ and $(12 \%, 36 \%, 8 \%$ and $9 \%)$ respectively, compared to the ridge width $50 \mathrm{~cm}$, ridge height $0 \mathrm{~cm}$ (flat soil), traditional tillage system and the first season.

8. The highest average increasing percentages in wheat grain yield and water productivity achieved at the ridge width $90 \mathrm{~cm}$, ridge height $50 \mathrm{~cm}$, conservation tillage system and the third season of field experiment application, were about $(32 \%, 92 \%, 19 \%$ and $26 \%)$ and $(12 \%, 28 \%, 10 \%$ and $10 \%)$ respectively, compared to the ridge width $50 \mathrm{~cm}$, ridge height $0 \mathrm{~cm}$ (flat soil), traditional tillage system and the first season.

9. The highest average decreasing percentages in specific cost of production was achieved at the ridge width $90 \mathrm{~cm}$, ridge height $50 \mathrm{~cm}$, conservation tillage system and the third season of field experiment application, were about $(52 \%, 29 \%, 39 \%$ and $40 \%)$ respectively, compared to the ridge width $50 \mathrm{~cm}$, ridge height $0 \mathrm{~cm}$ (flat soil), traditional tillage system and the first season.

\section{References}

[1] Nones, Raymond 2010. Raised-Bed Vegetable Gardening Made Simple. Countryman Press. Retrieved March 2, 2012. ISBN 978-0-88150-896-3.

[2] Connor, D. J., Timsina, J. and Humphreys, E. 2003. Prospects for Permanent Beds for the Rice-Wheat System, Improving the
Productivity and Sustainability of Rice-Wheat Systems: Issues and Impacts", ASA Special Publication, Vol. 65, pp. 197-210.

[3] Fahong, W. W., Uquing, X. and Sarya, K. D. 2003. Comparison study on two different planting methods for winter wheat in china. Bed planting course, CIMMTY, Mexico.

[4] Mann, R. A., and Meisner, C. A. 2003. Proceedings of the national workshop on rice-wheat systems in Pakistan, 11-12 ${ }^{\text {th }}$ December 2002. Islamabad, Pakistan. A Rice Wheat Consortium Paper Series 15. pp. 2-3.

[5] Hobbs P. R. 2001. Tillage and crop establishment in South Asian rice-wheat systems: present and future options. Journal of Crop Production; 4 (1): 1-23.

[6] Evans, L. T. and Lee, S. Y. 1977. Nitrogen, phosphorus and water contents during grain development and maturation in wheat. Australia Journal Plant Physiology, 4, 799-810.

[7] Hobbs, P. R., Giri, C. G. and Grace, P. 1977. Reduced and zero tillage options for the establishment of wheat after rice in south Asia. RCW paper no. 2 Mexico, D.f: rice-wheat consortium for the indo-Genetic plains and CIMMYT.

[8] Hassan, A. A. (1988). Science and practice in agricultural crops, cucumbers (watermelon, melon, cucumber and zucchini). Al-Dar Al-Arabia pub., pp: 60-120.

[9] Singh, R. A. and Singh, R. G. 1992. Response of various methods on yield of wheat HUW 234. Agriculture Science Digest Kernel, 12, 217-218.

[10] Hameed, A. and Solangi, A. K. 1993. Water management strategies for area with poor drainage or shallow water table conditions, Proceedings of Irrigation System Management Research Symposium, Lahore, Pakistan.

[11] Ortega, L., A. Sayre, K. D. and Francis, C. A. 2000. Wheat nitrogen use efficiency in a bed planting system in northwest Mexico, Agron. J. 92 303-308.

[12] Yadav Ashok, R. K. Malik, Chouhan, B. S., Kumarv, R., Banga, R. S., Samar, S., Yadav, J. S., PUNIA, S. S., Rathre, S. S. and Sayre, K. D. 2002. Feasibility of raising wheat on furrow irrigated raised bed in southwestern Haryana. In international workshop proceeding in herbicide resistance and zero tillage in rice-wheat cropping system march 21-6 (2002), CCSHAU Hisar PP 201-206.

[13] Singh Samar, Ashok Yadav and Malik, R. K. 2002. Furrow-irrigated raised bed planting. A resource Conservation Technology for increasing wheat productivity in rice wheat. Pp. 198-200.

[14] Gupta, R. K., Hobbs, P. R., Ladha, J. K. and Probhakar, S. V. R. K. 2002. Resource conserving technologies: Transforming the rice-wheat systems of the Indo-Gangetic Plains. Rice wheat consortium- a success story. Bangkok: Asia Pacific Association of Agricultural Research Institutes.

[15] Hobbs, P. R. and Gupta, R. K. 2003. Resource conserving technologies for wheat in the rice-wheat systems. In: Improving productivity and sustainability of rice-wheat systems: Issues and impact. American Soc. Agron. Spec. Publ. 65: 149171.

[16] Tanveer, S. K, Hussain, I., Sohail, M., Kissana, N. S. and Abbas, S. G. 2003. Effect of different planting methods on yield and yield components of wheat. Asian j. of plant Sci; 2 (10): 811-813. 
[17] Fahong, W., Xuqing, W. and Sayre, K. 2004. Comparison of conventional, flood irrigated, flat planting with furrow irrigated, raised bed planting for winter wheat in China, Field Crops Res. 87 35-42.

[18] Roth, C. H, Fischer, R. A. and Meisner, C. A. 2005. Evaluation and performance of permanent raised bed cropping systems in Asia, Australia and Mexico edited ACIAR Proceedings No. 121.

[19] Meisner, C. A., Acevedo, E., Flores, D., Sayre, K. D., Ortiz-Monasterio, I., Byerlee, D. and Limon, A. 1992. Wheat production and grower's practices in the Yaqui Valley, Sonora, Mexico. Wheat Spec. Rep. 6.Intl. Maize and Wheat Impr. Cent. Mexico.

[20] Hobbs, P. R. and Morris, M. L. 1996. Meeting South Asia's Future Food Requirements from Rice-Wheat Cropping Systems: Priority Issues Facing Researchers in the Post Green Revolution Era. NRG Paper 96-01. Mexico, DF. CIMMYT.

[21] Sayre, K. D. and Ramos, O. H. M. 1997. Application of Raised Bed Planting System to Wheat. Wheat Special Report No. 31. Mexico, DF: CIMMYT.

[22] Malik, R. K., Gill, G. and Hobbs, P. R. 1998. Herbicide resistance: A major issue for sustaining wheat productivity in rice-wheat cropping systems in the Indo-Gangetic Plains. Rice-wheat consortium paper Ser. 3. Rice-wheat consortium for the Indo-Gangetic Plains. New Delhi, India.

[23] Ahmad, R. N., and Mahmood, N. 2005. Impact of raised bed technology on water productivity and lodging of wheat. Pakistan Journal of Water Resources, 9 (2), 29-32.

[24] Ahmad, I. M., Qubal, B., Ahmad, G. and Shah, N. H. 2009. Maize yield, plant tissue and residual soil $\mathrm{N}$ as affected by nitrogen management and tillage system. J. Agric. Biol. Sci. 1 (1), 19-29.

[25] Bakker, D., Hamilton, M., Hetherington, G. J. and Spann, R. 2010. Salinity dynamics and the potential for improvement of water logged and saline land in a Mediterranean climate using permanent raised beds. Soil Tillage Res. 110 (1), 8-24.

[26] Conservation Technology Information Center (CTIC) 1998. National survey of conservation tillage practices. West Lafayette: Conservation Tillage Center.

[27] Liao, Y. C., Han, S. M. and Wen, X. X. 2002. Soil water content and crop yield effects of mechanized conservation tillage-cultivation system for dry land winter wheat in the Loess tableland. Trans. CSAE 4, 68-71 (in Chinese).

[28] Fang, R. Y., Tong, Y. A., Zhao, E. L. and Liang, D. L. 2003. Effect of conservation tillage on moisture, fertility and yield in Weibei Highland. Agric. Res. Arid Areas 3, 54-57 (in Chinese).

[29] Gao, H. W., Li, W. Y. and Li, H. W. 2003. Conservation tillage technology with Chinese characteristics. Trans. CSAE 3, 1-4 (in Chinese).

[30] Sarya, K. D 2003. Raised bed system of cultivation for bad planning course. CIMMT, Apdo. 370, P. O. Box 60326, Houston. TX 77205, Mexico.

[31] Singh, Y. 2003. Crop Residue Management in Rice-Wheat System, RWCCIMMYT", Addressing Resource Conservation
Issues in Rice-Wheat Systems of South Asia: A Resource Book, Vol. 153, Rice-Wheat Consortium for the Indo Gangetic Plains-CIMMYT, New Delhi, India.

[32] Qiao, H., Liu, X., Li, W., Huang, W. and Li, C., Li, Z. 2006. Effect of deep straw mulching on soil water and salt movement and wheat growth. Chin. J. Soil Sci. 37 (5), 885-889.

[33] Govaerts, B., Sayre, K. D., Lichter, K., Dendooven, L. and Deckers, J. 2007. Influence of permanent raised bed planting and residue management on physical and chemical soil quality in rain fed maize/wheat systems. Plant and Soil 91: 39-54.

[34] Naresh R. K., Singh, B., Bansal Sangita, Malik Sunil, Rathi, R. C. and Singh, K. V. 2010. Raised Bed Controlled Traffic Farming for Sustainability of Vegetable Crop Production for Improving Livelihood of Western Indo Gangetic Plains Farmers", Zonal Seminar on Physiological and Molecular Interventions for Yield and Quality Improvement in Crop Plants, Sardar Vallabhbhai Patel University of Ag. \& Tech., Meerut, UP, pp. 102-115.

[35] Singh, U. P., Singh, Y., Singh, H. P. and Gupta, R. K. 2011. Performance of permanent raised bed planting in rice-wheat system ib Eastern Uttar Pradesh, India. Poster in Fifth World Congress on Conservation Agriculture (WCCA) in cooperating the third farming systems design conference in Australia.

[36] Swelam, A. 2015. Development of a cost-effective raised-bed machine for small-scale farms to improve land and water productivity in the Nile Delta of Egy. Science Impacts, Oct 4.

[37] Satti, H. Y., Qingxi, L., Jiajia, Y. u. and Dali, H. e. 2012. Design and test of a pneumatic precision metering device for wheat. CIGR Journal 14, 1 March: 16-25.

[38] Kepner, R. A., Bainer, R. and Barger, E. L. 1978. Principles of Farm Machinery. Ch 5, the AVI Publishing Company.

[39] Black, G. R. 1986. Bulk density. P. 374-390. In Page, et. El. (eds.). Methods of Soil Analysis, Part 1. Physical and Mineralogical Methods, Am. Soc. Agron. Inc. Medison. Wis. USA.

[40] Kostiakov, A. N. 1932. On the dynamics of the coefficients of water percolation in soils and of the necessity of studying it from a dynamic point of view for purposes of amelioration. Trans., 6th Committee Inter. Soc. Soil Sci., pp. 17-21.

[41] James, L. G. 1988. Principles of farm irrigation system design. John Willey \& Sons (ed.), New York, pp. 543.

[42] Hansen, V. W., Israelsen, O. W. and Stringharm, G. E. 1979. Irrigation principles and practices. $9^{\text {th }}$ ed., John Willey and Sons Inc., New York, USA.

[43] Israelsen, O. W. and Hansen, V. E. 1962. Irrigation principles and practices. $3^{\text {rd }}$ Ed. John Willey and Sons Inc., New York.

[44] Ali, M. H., Hoque, M. R., Hassan, A. A. and khair, A. 2007. Effects of deficit irrigation on yield, water productivity and economic returns of wheat. Agricultural water management, 92 (3): $151-161$.

[45] El-Awady, M. N. 1978. Engineering of Tractor and Agricultural Machinery. Text Book, (in Arabic), Fac. of Agric. Ain Shams Univ., Cairo, Egypt. 